\title{
Are great Cascadia earthquakes recorded in the sedimentary records from small forearc lakes?
}

\author{
A. E. Morey ${ }^{1}$, C. Goldfinger ${ }^{1}$, C. E. Briles ${ }^{2}$, D. G. Gavin ${ }^{3}$, D. Colombaroli ${ }^{4,5}$, and J. E. Kusler ${ }^{3}$ \\ ${ }^{1}$ College of Earth, Ocean, and Atmospheric Sciences, Oregon State University, Corvallis, Oregon, USA \\ ${ }^{2}$ School of Geography and Environmental Science, Monash University, Melbourne, VIC, Australia \\ ${ }^{3}$ Department of Geography, University of Oregon, Eugene, Oregon, USA \\ ${ }^{4}$ Institute of Plant Sciences, University of Bern, Bern, Switzerland \\ ${ }^{5}$ Oeschger Centre for Climate Change Research, University of Bern, Bern, Switzerland \\ Correspondence to: A. E. Morey (morey@coas.oregonstate.edu)
}

Received: 31 December 2011 - Published in Nat. Hazards Earth Syst. Sci. Discuss.: Revised: 28 March 2013 - Accepted: 30 April 2013 - Published: 9 October 2013

\begin{abstract}
Here we investigate sedimentary records from four small inland lakes located in the southern Cascadia forearc region for evidence of earthquakes. Three of these lakes are in the Klamath Mountains near the Oregon-California border, and one is in the central Oregon Coast range. The sedimentary sequences recovered from these lakes are composed of normal lake sediment interbedded with disturbance event layers. The thickest of these layers are graded, and appear to be turbidites or linked debrites (turbidites with a basal debris-flow deposit), suggesting rapid deposition. Variations in particle size and organic content of these layers are reflected in the density and magnetic susceptibility data. The frequency and timing of these events, based on radiocarbon ages from detrital organics, is similar to the offshore seismogenic turbidite record from trench and slope basin cores along the Cascadia margin. Stratigraphic correlation of these anomalous deposits based on radiocarbon ages, down-core density, and magnetic susceptibility data between lake and offshore records suggest synchronous triggering. The areal extent and multiple depositional environments over which these events appear to correlate suggest that these deposits were most likely caused by shaking during great Cascadia earthquakes.
\end{abstract}

\section{Introduction}

The Cascadia subduction zone (CSZ) is a long $(\sim 1000 \mathrm{~km})$ megathrust fault extending from northern Vancouver Island to Cape Mendocino, California. Subduction zone earth- quakes produce the largest releases of energy on Earth and have the potential to cause extensive damage and loss of life. The lack of seismicity on the CSZ over the past three centuries belies its potential for great earthquakes, and the limited historic data as a result inhibits our understanding of its seismic and aseismic activity. Attempts to quantify the temporal and spatial patterns of seismic activity using realtime measurements (GPS, strain meters) provide evidence of strain accumulation, but only for a small fraction of the most recent strain cycle. Longer records, spanning at least 10-20 cycles, are needed to identify long-term patterns of earthquake recurrence. Turbidite palaeoseismology can provide longer records by reconstructing earthquake histories from the sedimentary record of past earthquakes, and is being successfully used to identify earthquake magnitude, frequency, spatial and temporal rupture patterns, and relationships to regional fault systems at subduction zones globally.

Marine turbidite palaeoseismology has been used to reconstruct long earthquake chronologies, and is particularly useful at subduction zones where the fault cannot be observed directly. This method has been used to reconstruct earthquake chronologies that span more than $10000 \mathrm{yr}$, long enough to capture multiple earthquake cycles, whereas onshore coastal palaeoseismology uses the stratigraphic records of uplift and subsidence to reconstruct earthquake histories for up to $1000-3000 \mathrm{yr}$ (occasionally longer). Marine turbidite palaeoseismology has now been applied in Cascadia (Adams, 1990; Goldfinger et al., 2003a, b, 2008, 2009, 2012), Japan (Inouchi et al., 1996; Shiki et al., 2000b; Nakajima and Kanai, 2000; Noda, 2004; Ikehara et al., 2012), Chile (St-Onge et al., 2012), the Mediterranean (Anastasakis and 
Piper, 1991; Kastens, 1984; Pareschi et al., 2006; Nelson et al., 1995; Cita and Aloisi, 2000), the Arctic Ocean (Grantz et al., 1996), the Dead Sea (Niemi and Ben-Avraham, 1994; Migowski et al., 2004), Canada (St-Onge et al., 2004), northern California (northern San Andreas Fault; Goldfinger et al., 2003a, b, 2007, 2008); Sumatra (Patton et al., 2013), the Hikurangi margin (Pouderoux et al., 2012), and Haiti (McHugh et al., 2011).

Turbidites are also found in lake sediments, and turbidite palaeoseismology has become a useful tool to reconstruct earthquake chronologies from lakes in close proximity to crustal and subduction zone faults. The time span represented by these records is variable, but frequently surpasses $10000 \mathrm{yr}$. Lacustrine turbidite palaeoseismology has been used to reconstruct earthquake chronologies around the world, including Switzerland (Schnellman et al., 2002; Arnaud et al., 2006; Strasser et al., 2006), Chile, (Arnaud et al., 2006; Moernaut et al., 2007; Bertrand et al., 2008; Charlet et al., 2008), Argentina (Waldmann et al., 2008), Venezuela (Carrillo et al., 2008), France (Chapron et al., 1999; Arnaud et al., 2002; Guyard et al., 2007; Beck, 2009), Kyrghyzstan (Bowman et al., 2004), Japan, (Shiki et al., 2000a), Russia (Nelson et al., 1995), Canada (Doig, 1986, 1990, 1991), New Zealand (Orpin et al., 2010; Howarth et al., 2012), California (Smoot et al., 2000; Seitz and Kent, 2005; Kent et al., 2005; Brothers et al., 2009), Arizona (Twitchell et al., 2005), as well as in the vicinity of the CSZ at Lake Washington, USA (Karlin et al., 2004; Karlin and Abella, 1992, 1996). In favourable settings, reconstructions can reach 50000 yr (late-Pleistocene Lake Lisan, palaeo-Dead Sea; Marco et al., 1996). Interpretation issues include differentiating earthquake-generated deposits from those resulting from other sources (such as floods and postfire erosion), and proximity of lake to confounding sources of shaking (i.e. volcanoes and local faults other than the fault of interest).

In this paper we compare stratigraphic sequences from small inland lakes recovered from the central and southern Cascadia forearc region to the Cascadia marine record of great earthquakes to evaluate whether or not they also record strong shaking during great subduction zone earthquakes. First we briefly review methodology and concepts developed through the study of the Cascadia marine turbidite record. Then we describe anomalous deposits observed in the stratigraphic sequences from four small lakes in very different settings located in central and southern Oregon and northern California and compare them to similar features of turbidites in key marine sediment cores. We examine characteristics of some of the deposits in these sequences in detail to evaluate our interpretations, and discuss the possible lake processes that may have produced them. Finally, we compare the lake sequences to the Holocene turbidite sequences in key marine sediment cores from the Cascadia trench and slope basins to evaluate possible relationships between the records and the potential for synchronous recording of great earthquakes.

\section{Cascadia marine turbidite palaeoseismology}

Here we briefly describe the methods used to identify and test the triggering mechanism of CSZ deposits to differentiate seismogenic deposits from those of other origins, and describe the methods used to establish event timing.

Marine sediment cores (Fig. 1) along the CSZ contain Holocene turbidite sequences and most include the Mazama Ash datum ( $7627 \pm 150$ cal yr BP (calendar years before present), Zdanowicz et al., 1999), making the CSZ an ideal location for turbidite palaeoseismology. L. D. Kulm and students in the late 1960s and 1970s investigated the nature, distribution, and timing of these sequences in detail (i.e. Duncan, 1968; Griggs, 1969; Griggs and Kulm, 1970; Kulm et al., 1975) and thought they might represent earthquakes along the margin, although the lack of seismicity made such a hypothesis seem unlikely. Adams (1984) was the first to interpret the turbidite deposits in these cores as a result of coseismic turbidity currents triggered by great Cascadia earthquakes. After buried coastal marsh sequences on land were discovered and interpreted as a result of coseismic subsidence (Atwater, 1987), Adams (1990) developed the turbidite hypothesis further with straightforward tests of synchronous deposition. Adams (1990) suggested four possible mechanisms for turbidity current generation: (1) storm and wave loading, (2) great earthquakes, (3) tsunamis, and (4) sediment loading, and Goldfinger et al. (2012) added (5) crustal earthquakes, (6) slab earthquakes, (7) hyperpycnal flow, and (8) gas hydrate destabilization. Differentiating between earthquake-triggered turbidite deposits and those not triggered by earthquakes is primarily based on (1) sedimentological criteria of individual deposits to determine origin; and (2) regional correlation of deposits over large enough regions so that the best explanation is synchronous triggering by great earthquakes.

\subsection{Identifying earthquake-triggered turbidites in marine sediment cores}

\subsubsection{Sedimentological criteria}

Earthquake-triggered turbidites may in some cases be distinguished from those resulting from non-earthquake disturbances using sedimentological criteria (Nakajima and Kanai, 2000; Nakajima, 2000; Shiki et al., 1996, 2000a, b; Pouderoux et al., 2012). Earthquake-triggered density flows are created when shaking causes subaqueous failures and sediment entrainment producing a dense, sediment-laden flow which is transported downslope to the site of deposition. Characteristics of resulting deposits are variable depending on flow parameters, seafloor topography, and proximity to source (e.g. Amy et al., 2004; Kneller and McCaffrey, 2003; Alexander and Morris, 1994; Sumner et al., 2008). Turbidites, in their simplest form, are characterized by upwardfining graded beds (normal grading). Turbidites can also be 


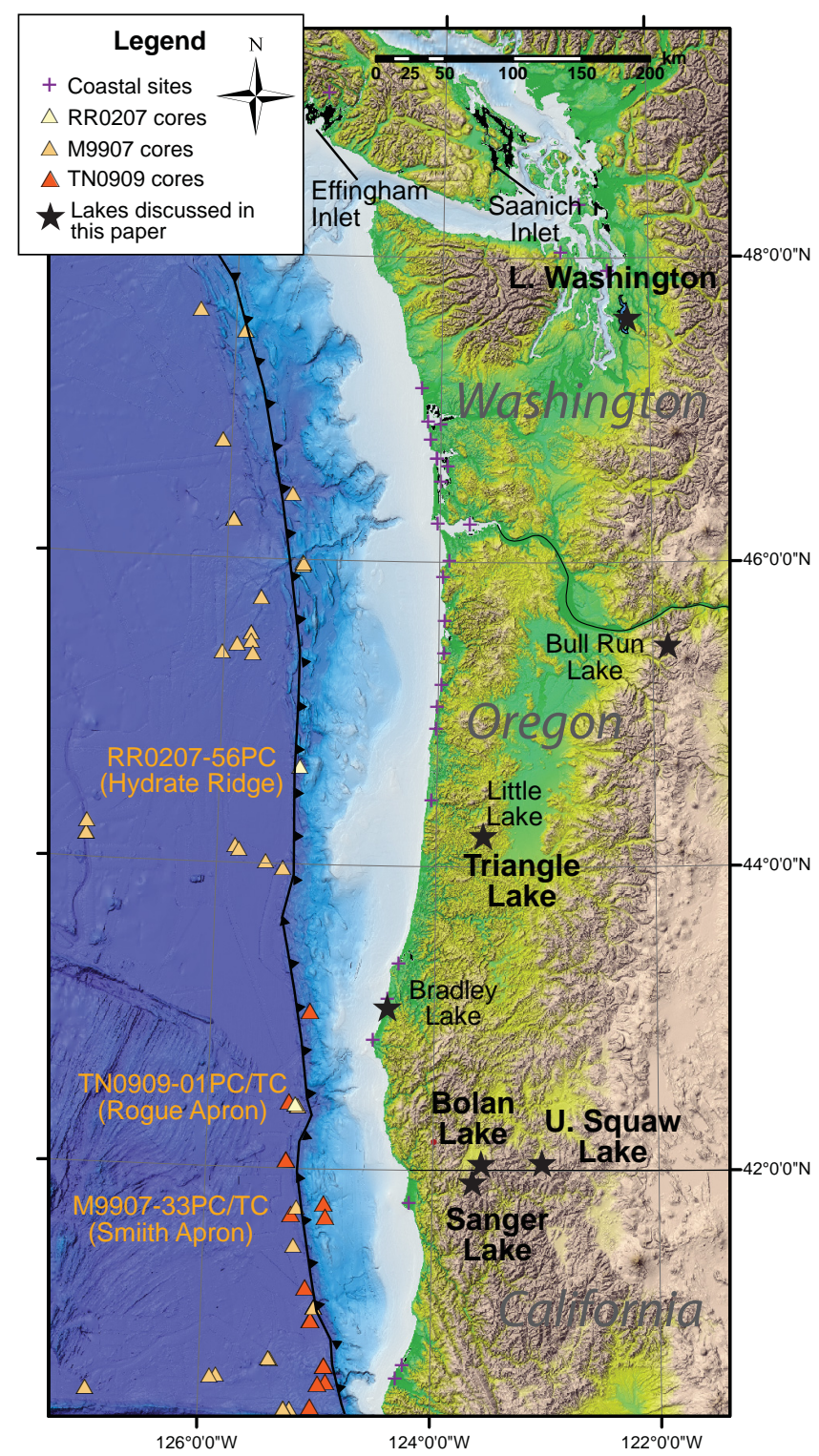

Fig. 1. Cascadia margin turbidite canyons, channels and 1999-2009 core locations. Bathymetric grid constructed from newly collected multibeam data in 1999, Gorda Plate swath bathymetry collected in 1997 (Dziak et al., 2001), and archive data available from NGDC. Triangles represent marine core locations for the 1999, 2002 and 2009 cruises. Lake sites discussed in this paper are identified with black stars.

very complex resulting in classic Bouma sequences (Bouma, 1962) or multi-pulsed or stacked turbidites (e.g. Tripsanas et al., 2008; Gutiérrez-Pastor et al., 2013). Unsorted coarse material may sometimes precede gravity flow deposits, resulting in a linked debrite when a debris-flow deposit is overlain by graded sediment as finer material settles out of suspension (Tripsanas et al., 2008). Wide areal extent and thickness (and therefore mass) of density flow deposits have been used as criteria along with sedimentological criteria to differentiate earthquake-generated deposits, however it is difficult to infer earthquake triggering without additional information.

The analysis of historic deposits can provide additional information which can be used to differentiate earthquaketriggered deposits to those from other causes in some cases. For example, hyperpycnites (deposits from a flood carrying a denser sediment/water mixture than the water in the receiving basin) typically show reverse, then normal, grading representing the waxing and waning of the flow (i.e. Mulder et al., 2001). St-Onge et al. (2004) analysed a sedimentary sequence from Saguenay Fjord, Québec, that was produced from a known historic earthquake followed by a flood (landslide dam breach). The analysis showed that the hyperpycnite deposit resulting from the flood has reverse, then normal, grading whereas the earthquake-triggered turbidite deposit has normal grading. The authors applied the observed characteristics to identify earthquake-triggered turbidites from the prehistoric deposits in the core.

Historical data are not always available to differentiate between triggers. Density flow deposit thickness and wide areal extent have been used, along with sedimentological criteria, to identify earthquake-generated deposits when historical data does not exist. It is difficult, however, to infer earthquake triggering without additional information. One of the most compelling arguments for earthquake-triggering can be made if synchronous triggering of density flows can be determined over very large areas and within different marine channel systems (Adams, 1990; Goldfinger et al., 2003a, b, 2008, 2012).

\subsubsection{Synchronous triggering}

Synchroneity has been inferred based on multiple lines of evidence from (1) sequences within a single channel system (channel confluence test), (2) comparison of deposits from independent channel systems (stratigraphic correlation over large distances), and (3) seismic correlation of deposits between channel systems. These methods are described below.

\section{Channel confluence test}

Synchronous triggering can be inferred if the number of deposits is the same above and below a channel confluence. Adams (1990) examined core logs from previously collected Cascadia Channel cores and determined that many had 12 turbidites overlying a 13th turbidite that bore the Mazama Ash. Adams observed that cores from Juan de Fuca, Willapa, Grays, and Quinault canyons all contain 12-16 turbidites above the first turbidite emplacement of the Mazama Ash. The core sites in these channels are $50-150 \mathrm{~km}$ apart, and are upstream from the confluence where they converge and become the Cascadia Channel. If these events had been independently triggered, with more than a few hours separation in time, the channels below the confluence should contain between 26 and 32 turbidites, not 13 as observed. 
Similar inferences about regionally triggered synchronous turbidites in separate channels have been reported elsewhere (Pilkey, 1988; Nakajima and Kanai, 2000; Shiki et al., 2000b; Gorsline et al., 2000).

\section{Stratigraphic correlation}

Synchronous triggering of turbidity flows in independent channels can be inferred if the resulting deposits are correlated over large distances, and can be attributed to a subduction zone earthquake if over a large enough distance that it is the only logical explanation. Correlation is performed using physical property data (gamma density, computed tomography (CT) density, magnetic susceptibility, and $p$-wave velocity data), particle-size data, and lithologic descriptions in conjunction with radiocarbon ages. The physical property data are proxies for vertical patterns in particle-size and sediment composition in the sedimentary sequence. Goldfinger et al. (2012) demonstrate that in Cascadia the similarities of vertical profiles of the physical property data for individual deposits extend beyond individual sites, including sites within individual channels, channel systems that merge, and more surprisingly, between channels that never meet. These correlation methods are a common practice with ODP (Ocean Drilling Program) cores, oil industry, and recently palaeoseismology (i.e. Abdeldayem et al., 2003; St-Onge et al., 2003; St-Onge and Lajeunesse, 2007; Hagstrum et al., 2004; Iwaki et al., 2004; Karlin et al., 2004; Schnellmann et al., 2002; Goldfinger et al., 2007, 2008; Patton et al., 2010, 2011; Gràcia et al., 2010; Lees et al., 1998; Wynn et al., 2002). Because Cascadia turbidite characteristics persist over large distances and across varied depositional environments, transport regimes, and physically isolated sites, the conclusion is that the patterns must have resulted from a common trigger, most likely a subduction zone earthquake (Goldfinger et al., 2008, 2011, 2012).

\section{Seismic correlation}

Cascadia turbidites can also be traced long distances with lateral continuity using seismic profile data supporting a regional triggering mechanism not linked to the canyon systems. Approximately $1900 \mathrm{~km}$ of continuous $3.5 \mathrm{kHz}$ subbottom profiles were collected with a Knudsen 320 BR (FM chirp mode sweeping 2-6 kHz) along the southern Cascadia margin in 2009. These profiles are located along the CSZ trench axis, with a number of partial strike lines, as well as longitudinal lines through and connecting the slope basin sites. These profiles imaged individual turbidites in the Holocene section in $1500-3100 \mathrm{~m}$ water depth with a vertical resolution of $\sim 18 \mathrm{~cm}$. A comparison of turbidite sequences from sediment cores to the seismic profiles suggests sheet-like turbidity deposits between core sites as widespread non-channelized deposition, interrupted infrequently by lo- cal landslides in both basin and trench sites (Goldfinger et al., 2013).

\section{Lake turbidite palaeoseismology}

Lakes are also good recorders of disturbance events because the contrast between terrigenous layers typical of the resulting deposits and the more organic-rich background sediment in many lakes is apparent and additional earthquake evidence may be present in close proximity. Earthquakeinduced disturbance of lake sediments can take many forms, and includes microfracturing, fluidization and liquefaction features (Beck, 2009; Obermeier, 2009) and seismites (in situ earthquake-induced deformation structures in soft sediment; e.g. Bowman et al., 2004; Shiki et al., 2000b; Carrillo et al., 2008). Homogenites and turbidites are typically visible, thick, basin-wide deposits and are best suited for large-scale palaeoseismology (e.g. Orpin et al., 2010; Strasser et al., 2007; Karlin et al., 2004; Seitz and Kent, 2005; Strasser et al., 2006). As with marine turbidite palaeoseismology, turbidite characteristics have been correlated within lake basins and fjords to establish stratigraphic continuity and suggest earthquake triggering (Karlin et al., 2004; Seitz and Kent, 2005; Guyard et al., 2007; Waldman et al., 2008). Interpretation of lake sedimentary and deformation history has improved over the last decade through the use of high-resolution chirp profiles (e.g. Kulbe et al., 2005; Schnellmann et al., 2002, 2006; Charlet et al., 2008; Beck, 2009; Lauterbach et al., 2012), and allowed for reconstructions of magnitude and epicentral locations from slope-failure deposits (Strasser et al., 2006).

\subsection{Cascadia inland lakes as recorders of great earthquakes}

A Cascadia subduction zone earthquake of $M_{\mathrm{w}}=9$ would produce severe shaking along the coast, and strong to very strong shaking (peak acceleration: 9$34 \% \mathrm{~g}$, peak velocity: $8-31 \mathrm{~cm} \mathrm{~s}^{-1}$; USGS Shakemap Scenario, http://earthquake.usgs.gov/earthquakes/shakemap/ global/shake/Casc9.0_se/) as far inland as the Cascade Range foothills. Peak ground acceleration values were recorded for the first time during a great subduction earthquake by strong motion instruments during the Tohoku earthquake of 2011 revealing accelerations of $1.0-1.5 \mathrm{~g}$ at stations as far as 20 $40 \mathrm{~km}$ from the coast, and over $200 \mathrm{~km}$ from regions of significant slip, as well as revealing a temporal pattern of multiple slip events of the main rupture patch over the $160 \mathrm{~s}$ duration of the event (Lee et al., 2011). Although geotechnical parameters and lake settings are highly variable, recent studies suggest that as little as $0.17 \mathrm{~g}$ would be required to destabilize lake sediments (Charlevoix seismic zone, Ouellet, 1997). If applicable to Cascadia, forearc lakes in Cascadia should contain evidence of past earthquakes. 
Many lakes in the Cascadia forearc have high sediment accumulation rates, contain sedimentary records extending into the late Pleistocene, and often have anoxic bottom waters that limit bioturbation making them excellent recorders of local and regional events. As a result, lakes west of the Cascade Range have been cored and used extensively for reconstructions of climate, vegetation and fire history (e.g. Dearing and Jones, 2003; Karlin et al., 2004; Long et al., 1998; Briles et al., 2008; Whitlock et al., 2008; Long et al., 2007; Walsh et al., 2010; Prichard et al., 2009; Long and Whitlock, 2002, and many others). Cascadia forearc lakes have not been considered good candidates for palaeoseismology because many are small with limited clastic input due to their heavily forested catchments and lack of large elevation gradients. Ideal lake settings for palaeoseismology are typically large, steep-sided lakes with a large sediment supply, such as is the case with the only published example of Cascadia lake turbidite palaeoseismology, which is from Lake Washington in Washington State (Karlin and Abella, 1992, 1996; Karlin et al., 2004).

This investigation of disturbance event deposits in Cascadia lake records came from the observation that published sediment core records from Cascadia forearc lakes contain anomalous deposits with a higher percentage of terrigenous sediment and magnetic susceptibility variability that looks remarkably similar to the physical property signatures of offshore turbidites with similar timing and frequency. We describe these sites and others used in this investigation, and then apply methods from both marine and lake turbidite palaeoseismology to determine if deposits show evidence of synchroneity when compared to other lake and marine records, from which we can infer they record great Cascadia earthquakes.

\subsection{Alternative explanations for anomalous terrigenous layers in lake sediments}

Lacustrine terrigenous layers with low organic content relative to the background have been attributed to increased sediment transport into lakes as a result of post-fire erosion (Millspaugh and Whitlock, 1995), extreme meltwater events (C. E. Briles, personal communication, 2010, Parris et al., 2010), increased runoff following severe storms (e.g. Noren et al., 2002), and increased erosion after land clearance and road building (Colombaroli and Gavin, 2010). There are no definitive tests that can positively identify an earthquake source mechanism, though arguments for internal or external sources of sediment to the lake have been made on the basis of grading characteristics, chemistry, and diatom assemblages (e.g. Orpin et al., 2010). Here we review event triggers other than earthquakes to explain the presence of rapidly deposited terrigenous layers in lake sediments.

\subsubsection{Forest fires}

Terrigenous layers with a high ratio of clastics to organics in lake sediments have been attributed to increased erosion after severe forest fires (e.g. Millspaugh and Whitlock, 1995; Gedye et al., 2000; Millspaugh et al., 2000; Colombaroli and Gavin, 2010; Whitlock et al., 2003; and many others). Charcoal accumulation rate peaks are used as a proxy for forest fire frequency (e.g. Whitlock et al., 2003). Particulate charcoal is introduced into the lake through airborne fallout, transport via streams, and washed in from the slopes surrounding the lake. The relationship between historic fire data and macroscopic charcoal $(>100 \mu \mathrm{m})$ peaks supports the use of this proxy to reconstruct fire frequency (Millspaugh and Whitlock, 1995). Modern calibration studies and theory support the interpretation of large charcoal accumulation rate peaks with associated erosional events as a result of severe fire, and that the fire intensity signal is stronger than the influence from fire proximity or extent (Higuera et al., 2007; Whitlock and Larsen, 2001; Duffin et al., 2008), however the lack of correlation between charcoal peaks and terrigenous deposits has been noted for some Cascadia lake sediments (e.g. Long et al., 1998; Long and Whitlock, 2002).

Relevant to this study is the investigation of the fire history recorded at Little Lake, Oregon (central Oregon Coast range), by Long et al. (1998) who show that charcoal accumulation rate peaks do not correlate with the magnetic susceptibility records $(r=0.288)$ at that site. Charcoal accumulation rate peaks, however, correlate well with shifts in vegetation as inferred from pollen analyses, with peaks in charcoal accumulation rates corresponding to increases in disturbance-adapted species. The authors speculated that peaks in magnetic susceptibility were a result of episodes of mass movement within the watershed caused by fire, storms or earthquakes. Likewise, charcoal peaks at Bolan and Sanger lakes are not always associated with magnetic susceptibility peaks (C. E. Briles, personal communication, 2010).

\subsubsection{Floods}

Floods are known to increase sediment transport in rivers and produce terrigenous layers in lakes (e.g. Adams, 1980; Noren et al., 2002, and others) which are visually apparent especially when interbedded with organic-rich lake sediments. Flooding is common in the Pacific Northwest of North America, especially if large, warm rainstorms coincide with early or late season snowmelt. The desire to reconstruct environmental conditions and related natural hazards from lake sediments such as "storminess", precipitation, and floods has resulted in a recent increase in the number of studies where the authors attempted to differentiate between earthquaketriggered mass deposits and flood deposits. These studies suggest that flood deposits are more likely to have reverse, then normal grading (Mulder et al., 2003; St-Onge et al., 2004; Beck, 2009; Wirth et al., 2011; Gilli et al., 2013). 
For deposits interpreted as resulting from floods with both types of grading, see Simonneau et al. (2013). It has been observed that flood deposits are thinner than earthquaketriggered deposits (e.g. Sturm et al., 1995), and become thinner (or disappear) with distance from the lake inlet (Brown et al., 2000; Karlin et al., 2004; A. Noren, personal communication, 2013).

Sediments from Lake Washington in Seattle, Washington, were evaluated for flood deposits using historical records of floods and storms (Karlin et al., 2004). The authors argue that seismogenic turbidites are not likely to be confused with storm-generated deposits because even the most severe historical (post-1916) storm deposits represented in Lake Washington are very thin $(\sim 0.5 \mathrm{~mm})$ discontinuous stringers of clay with no magnetic susceptibility signature present only near the mouth of the river. In contrast, layers interpreted as seismogenic do not thin from the mouth of the input source, the Sammamish River, as would be expected if they were storm generated (Karlin et al., 2004). The more massive turbidite deposits, subaqueous landslides, and slumps found throughout the entire lake appear to be synchronous as well as having a timing and frequency that is not similar to that of large storms, but instead closely matches the Cascadia tsunami and earthquake record from coastal and offshore sites (Karlin et al., 2004).

In another relevant study, St-Onge et al. (2004) described six sequences of earthquake-triggered turbidite deposits with fining upward sequences overlain by hyperpycnites, with reverse, then normal, grading. These deposits were interpreted, based on observations from an earthquake in the area from AD 1663, as representing an earthquake followed by a flood deposit resulting from the breach of an earthquake-triggered landslide dam. It has become somewhat common to differentiate between earthquake-generated (or natural) masswasting deposits with fining upward sequences and flood deposits with reverse, then normal, grading sequences in lake sediments (Mulder et al., 2003; St-Onge et al., 2004; Beck, 2009; Wirth et al., 2011). Alternatively, the sediment cores (from areas with little to no seismicity) used by Noren et al. (2002) show reverse and/or normal grading, and sometimes are massive ungraded deposits (A. Noren, personal communication, 2013).

\subsubsection{Climate}

Changes in climate can also influence the amount of allochthonous terrigenous sediment in a lake. Strong winds could result in large enough waves to destabilize lake margin sediments, although deposits resulting from these mechanisms would most likely be local, and not correlate long distances. Climate may be coupled with other events influencing the sedimentation in the lake as well. For example, extreme drought is correlated to fire frequency (Westerling et al., 2006) and extreme precipitation can result in increases in the number of landslides (e.g. Aleotti, 2004 and references therein). Earthquake-triggered turbidites and homogenites are a result of mass movements that are deposited instantaneously (minutes to days), whereas floods and postfire erosion would introduce more allochthonous terrigenous sediment over a greater period of time (weeks to decades or more), however it is difficult to detect this time difference from deposit characteristics.

Although studies have shown promise in differentiating between mechanisms, deposit lithologies of earthquaketriggered flood deposits and extreme erosion events (e.g. post-fire erosion) are highly variable and identifying the source mechanism is difficult from sedimentological criteria alone. Here we emphasize large-scale correlation over large distances and multiple environments as the primary method for identifying earthquake triggering, and use preliminary sedimentological analyses as supporting evidence.

\section{Methods}

We use previously collected cores along with the original published data and new data, in addition to one new core (Sanger Lake, CA) for this study. In this section, we describe the sites, discuss how the physical property data can be interpreted, describe the differences between marine and lacustrine radiocarbon dates used in this study, and then explain how disturbance events are identified prior to comparison to the marine record.

\subsection{Locations of sediment cores used in this study}

\subsubsection{Sanger Lake, California, USA}

Sanger Lake $\left(41^{\circ} 54^{\prime} 06^{\prime \prime} \mathrm{N}, 123^{\circ} 38^{\prime} 49^{\prime \prime} \mathrm{W}\right)$ is a $4 \mathrm{ha}$, predominantly spring-fed cirque lake at $1550 \mathrm{~m}$ elevation in the Siskiyou Mountains located $\sim 46 \mathrm{~km}$ from the coast near the Oregon/California border (Fig. 2a). The sediment core from this site was originally published in Briles et al. (2008). Intermittent streams make their way to the lake from the east, but most of the water disappears underground before arriving at the lake through what has been interpreted as a landslide ( $\sim 750 \mathrm{~m}^{2}$ in area) from an upslope glacier (based on an unpublished aerial photo interpretation by the Six Rivers National Forest; H. Klingel, personal communication, 2010). A $6.66 \mathrm{~m}$ long sediment core (and associated surface short core) representing $14500 \mathrm{yr}$ was extracted from near the centre of the lake at $\sim 7.6 \mathrm{~m}$ water depth using a Livingstone squarerod piston sampler. Magnetic susceptibility was measured at $1 \mathrm{~cm}$ contiguous intervals using a Bartington magnetic susceptibility meter equipped with a cup sensor. Magnetic susceptibility data were scaled and log transformed (natural log) to improve the resolution of low amplitude events otherwise obscured by scaling to extreme values. The Mazama Ash occurs at $3.96 \mathrm{~m}$, and multiple ${ }^{210} \mathrm{~Pb}$ and radiocarbon dates exist throughout the core. 
A second core (SL2010), $147.5 \mathrm{~cm}$ long, was acquired using a Klein corer in September of 2010. CT volume density data were acquired for this core using a Toshiba Aquillon 64-slice system with 3-D voxel resolution of $0.35 \mathrm{~mm}$. The sedimentary sequence from $\sim 102$ to $112 \mathrm{~cm}$ was photographed, lithology described, sampled at $0.5 \mathrm{~cm}$ for grainsize analysis, and sieved at $125 \mu \mathrm{m}$ to determine the composition of coarse material for selected units. Correlation to the original published core indicates the core represents $\sim 0$ 2000 cal yr BP. We acquired grain-size data for samples at half-centimetre increments through a $10 \mathrm{~cm}$ section of the 2010 Sanger Lake core with large shifts in grain size and sediment composition. Analyses were performed with the laser diffraction method using a Beckman-Coulter LS 13-320 laser counter (Blott and Pye, 2006) after digesting organics using a $25 \%$ hydrogen peroxide treatment for $24 \mathrm{~h}$. Six additional $\sim 0.5 \mathrm{cc}$ samples were removed from the same $10 \mathrm{~cm}$ interval and sieved at $125 \mu \mathrm{m}$ for description.

\subsubsection{Bolan Lake, Oregon, USA}

Bolan Lake $\left(42^{\circ} 01^{\prime} 19.21^{\prime \prime} \mathrm{N}, 123^{\circ} 27^{\prime} 33.09^{\prime \prime} \mathrm{W}\right)$ is a 5 ha spring-fed cirque lake at $1638 \mathrm{~m}$ elevation in the Siskiyou Mountains $\sim 65 \mathrm{~km}$ from the coast near the Oregon/California border. The sediment core from this site was originally published in Briles et al. (2005, 2008). An $8.97 \mathrm{~m}$ sediment core representing approximately $17000 \mathrm{cal}$ yr BP was recovered from near the centre of the lake, which is approximately $11.3 \mathrm{~m}$ deep. Magnetic susceptibility was measured at $1 \mathrm{~cm}$ contiguous intervals using a Sapphire Instruments magnetic susceptibility meter equipped with a cup sensor. Magnetic susceptibility data were scaled and $\log$ transformed (natural $\log$ ) to improve the resolution of low amplitude events otherwise obscured by scaling to extreme values. The only visible inorganic layer is the basal unit from approximately $17000-14500$ calyr BP of green clay, although laminated sediments and several stones were found between 12200 and 10900 cal yr BP. The Mazama Ash occurs at $4.86 \mathrm{~m}$, and multiple ${ }^{210} \mathrm{~Pb}$ and radiocarbon dates exist throughout the core.

\subsubsection{Upper Squaw Lake, Oregon, USA}

Upper Squaw Lake $\left(42^{\circ} 01^{\prime} 55^{\prime \prime} \mathrm{N}, 123^{\circ} 00^{\prime} 56^{\prime \prime} \mathrm{W}\right)$ is a 7.2 ha landslide-dammed lake at $930 \mathrm{~m}$ elevation in the Siskiyou Mountains $\sim 105 \mathrm{~km}$ from the coast near the Oregon/California border. This core was originally published in Colombaroli and Gavin (2010). This lake drains a $40 \mathrm{~km}^{2}$ watershed with $1020 \mathrm{~m}$ of relief, resulting in the highest sedimentation rate of the cores investigated. Two sediment cores with overlapping sections were extracted from the near the centre (water depth of $14.1 \mathrm{~m}$ ) of the lake, which were correlated and compiled to create a continuous $10 \mathrm{~m}$ core that records events during the past $2000 \mathrm{yr}$. Magnetic susceptibility was measured contiguously at $1 \mathrm{~cm}$ intervals on the unsplit $5 \mathrm{~cm}$ diameter sediment cores using an $8 \mathrm{~cm}$ diameter Sapphire Instruments meter equipped with a loop sensor; values have not been log transformed. The 1964 ${ }^{137} \mathrm{Cs}$ peak was located by iterative measurements, and along with five radiocarbon dates throughout the core, provide the chronology. Charcoal was extracted at $1 \mathrm{~cm}$ contiguous intervals throughout the core, and biogenic silica and pollen at $\sim 20 \mathrm{~cm}$ (Colombaroli and Gavin, 2010). These authors created two age models: the first used the radiocarbon ages and the $1964{ }^{137} \mathrm{Cs}$ peak to constrain the sequence. The second applied a correction based on a function using magnetic susceptibility, where high values of magnetic susceptibility represent instantaneous deposition. The use of this magnetic susceptibility-based age model reflected Colombaroli's and Gavin's recognition that layers with high magnetic susceptibility were quickly deposited.

\subsubsection{Triangle Lake, Oregon, USA}

Triangle Lake $\left(44^{\circ} 10^{\prime} 22^{\prime \prime} \mathrm{N}, 123^{\circ} 34^{\prime} 22^{\prime \prime} \mathrm{W}\right)$ is a 119 ha, $29.6 \mathrm{~m}$ deep, landslide-dammed lake at $212 \mathrm{~m}$ elevation on the eastern flank of the Oregon Coast range approximately $43 \mathrm{~km}$ from the coast. Two sediment cores with overlapping sections producing an $8 \mathrm{~m}$ composite representing $6000 \mathrm{yr}$ were extracted from a depth of about $24 \mathrm{~m}$ using a Livingstone piston corer (Kusler and Gavin, 2011; unpublished data). Triangle Lake is deep enough to become thermally stratified in the summer with seasonal turnover (Atlas of Oregon Lakes, http://aol.research.pdx.edu/?q\$=\$lake/386), suggesting the lake may not be anoxic year-round and could result in mixing of surface sediments; the presence of vivianite in the sediments, however, suggests extended periods of anoxia (Kusler and Gavin, 2012; unpublished data). Magnetic susceptibility readings were taken using a Geotek XYZ MSCL split-core logger using a Bartington MS2E point sensor. Three radiocarbon dates provide age control. Little Lake, formed by the same landslide that created Triangle Lake, provides a similar magnetic susceptibility record (not shown here; published in Long et al., 1998).

\subsection{Lithology proxies}

The sedimentology of each lake varies by lake type and setting, and these differences are reflected in the physical property data. The most commonly acquired properties of lake sediment cores have been loss on ignition (LOI; \% of organic material) for vegetation and fire history studies for use in conjunction with pollen and/or charcoal counts. More recently, it has become common practice to acquire magnetic susceptibility, gamma density, and CT density imagery for sediment cores from both marine and lake settings. The interpretation of variability in these physical properties depends on setting. For example, magnetic susceptibility is typically interpreted as a proxy for grain-size and mineral composition of marine sediment cores, whereas magnetic 
susceptibility data from lake cores is typically interpreted to reflect changes in the amount of allochthonous inorganic sediment carried into the lake basin as a result of watershed events such as forest fire (post-fire erosion; Thompson and Oldfield, 1986; Millspaugh and Whitlock, 1995) and extreme hydrologic events (flood deposits; Brown et al., 2000; Noren et al., 2002). Here we present the sedimentological characteristics for each lake core and the associated influence of the compositional differences on the physical property data.

Sanger and Bolan lakes (Fig. 2a, b) are both high elevation, predominantly spring-fed cirque lakes in close proximity ( $\sim 20 \mathrm{~km}$ apart). LOI and magnetic susceptibility data reflect the decrease in terrigenous input associated with the recession of glaciers in the mountain peaks upslope. Late Pleistocene deposits consist of glacial clays and silts with lower (10-15\%) organic content which transitions to fine and medium detritus gyttja comprised of $\sim 30 \%( \pm 5 \%)$ organic content throughout much of the Holocene. The temporal variability of the magnetic susceptibility data is negatively correlated to the amount of organic material in these cores (Briles et al., 2005, 2008). These records are punctuated by periodic drops in the organic content by about $10 \%$, with associated increases in magnetic susceptibility. The records at Bolan and Sanger diverge at about 1500 calyr BP. Most notable are excursions in magnetic susceptibility and LOI content data in the Sanger Lake core associated with thick visible silt and clay layers that are not present in the Bolan Lake core. The thickest of these layers is a $7-10 \mathrm{~cm}$ thick silt and clay layer from $\sim 0.42-0.33 \mathrm{~m}$ with high values of magnetic susceptibility, which occurs at a roughly similar sediment depth and thickness throughout the entire lake, and was originally interpreted as an extreme meltwater event (C. E. Briles, personal communication, 2010). A layer of abundant plant macrofossils was originally described from the core below the silt and clay layer, however the magnetic susceptibility is high and \% of organic content is low (20\%) as compared to background sediment, a result of the large amount of sand that is also mixed in with the macrofossils.

Upper Squaw and Triangle lakes are both landslidedammed lakes with higher overall sedimentation rates as compared to Sanger and Bolan lakes. These sites have large drainage areas (Upper Squaw Lake drains $\sim 40 \mathrm{~km}^{2}$, with $\sim$ $1100 \mathrm{~m}$ elevation change, and Triangle Lake drains $143 \mathrm{~km}^{2}$, with $\sim 400 \mathrm{~m}$ of elevation change). The core from Upper Squaw Lake contains faint and distinct laminations consisting of silty gyttja and interbedded inorganic turbidites varying in thickness from $1 \mathrm{~mm}$ to more than $20 \mathrm{~cm}$ (Colombaroli and Gavin, 2010). The top $2.8 \mathrm{~m}$ is marked by homogeneous inorganic material, which was rapidly deposited during the past century and has been attributed to land-use changes such as logging, road building and land clearance (Colombaroli and Gavin, 2010).

The magnetic susceptibility data for the Upper Squaw Lake core are highly variable through time (Fig. 2c). Lightest grey layers have highest values, and they are also denser (brighter in CT imagery) than other layers in the core (see inset). In contrast, Triangle Lake (Fig. 2d) is more uniform in colour throughout, with five visible layers that are lighter in colour with very high magnetic susceptibility. The overall organic content is low, averaging about $12 \%( \pm 4 \%)$ for the entire core.

\subsection{Identifying disturbance event layers}

Disturbance event layers were identified from the original core descriptions for all cores except the Bolan Lake core. The described deposits are visibly lighter in colour because they have a higher ratio of lithics to organics as compared to surrounding sediment. These disturbance events are associated with the highest peaks in magnetic susceptibility and are denser than nearby sediment. The cores also have peaks in magnetic susceptibility where a visible layer was not described; and the additional available data show they are also associated with denser sediment with a lower organic content than surrounding sediment. Magnetic susceptibility data are fast and easy to acquire, it is a non-destructive method, and is available for all cores at high resolution (typically $1 \mathrm{~cm}$ or less, unlike the other sediment properties). Magnetic susceptibility is also acquired at high resolution for marine sediment cores, as it is a proxy for particle size for these graded deposits. We selected peaks in magnetic susceptibility above background levels for this investigation as our proxy for disturbance event layers to compare to records of magnetic susceptibility from both marine and lake to determine if they correlate. This is a simplistic but conservative approach to identifying disturbance event deposits in these sedimentary records. It is, however, our objective to determine if the deposits correlate over a large areal extent to infer earthquake triggering, not to reconstruct earthquake chronologies at these sites.

\subsection{Radiocarbon ages}

Ages for both lake and marine records are the result of standard AMS (accelerator mass spectrometer) radiocarbon methods, however sampling strategies and datable material differ depending on depositional environment.

All marine radiocarbon ages are from Goldfinger et al. (2012). Marine sediment samples are typically $3 \mathrm{~cm}$ thick intervals taken just below a turbidite to avoid the upper boundary between the finest material (turbidite tail) and hemipelagic background sediment which is frequently bioturbated and difficult to identify. The calcium carbonate shells of planktonic foraminifers were extracted from the samples for AMS radiocarbon analysis, and resulting ages are interpreted to represent the vertical midpoint of the sample assuming an even distribution of foraminifers within the sample. Because radiocarbon samples were taken below turbidites, Goldfinger et al. (2012) adjusted ages upward to reflect the depositional age using the amount of sediment 

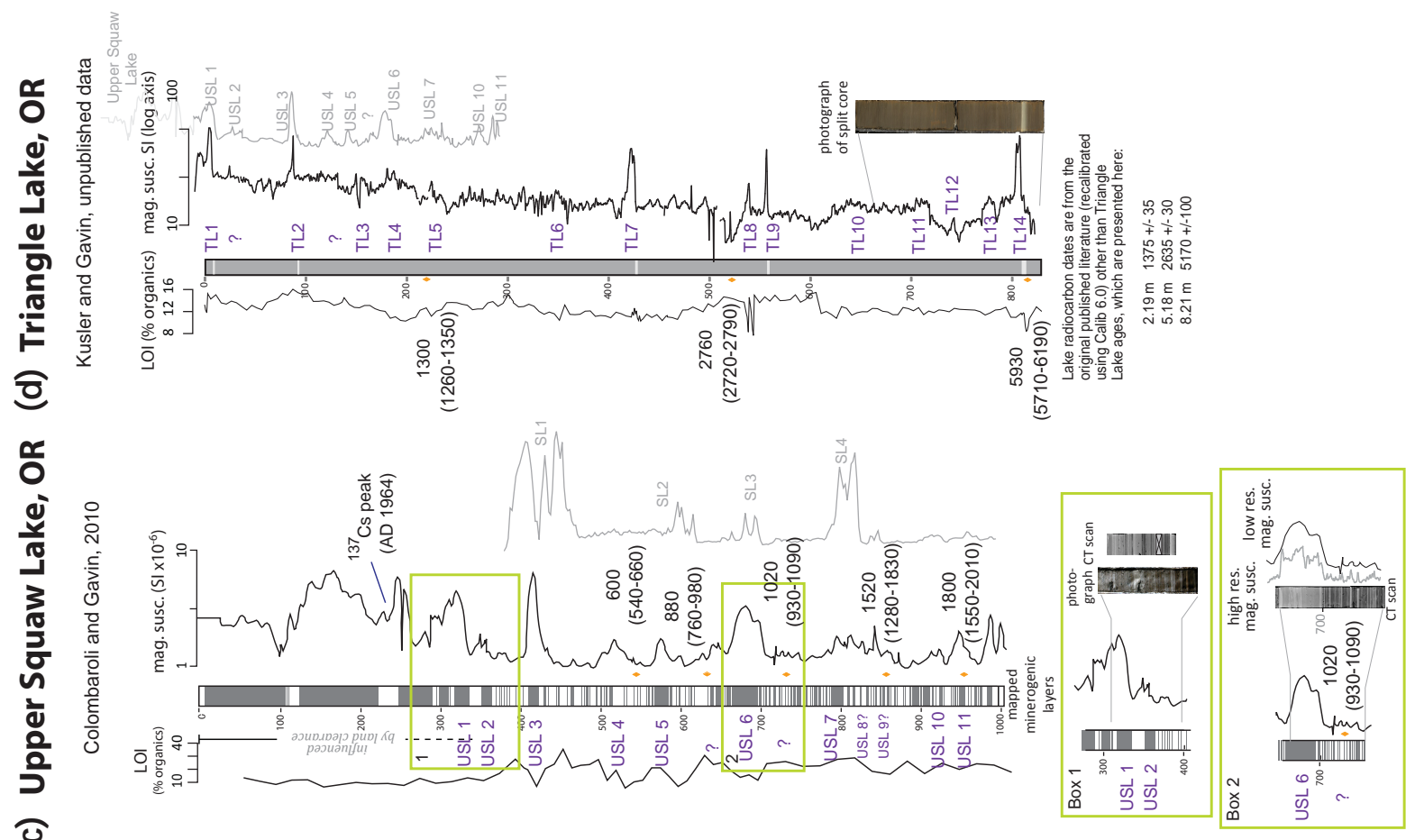

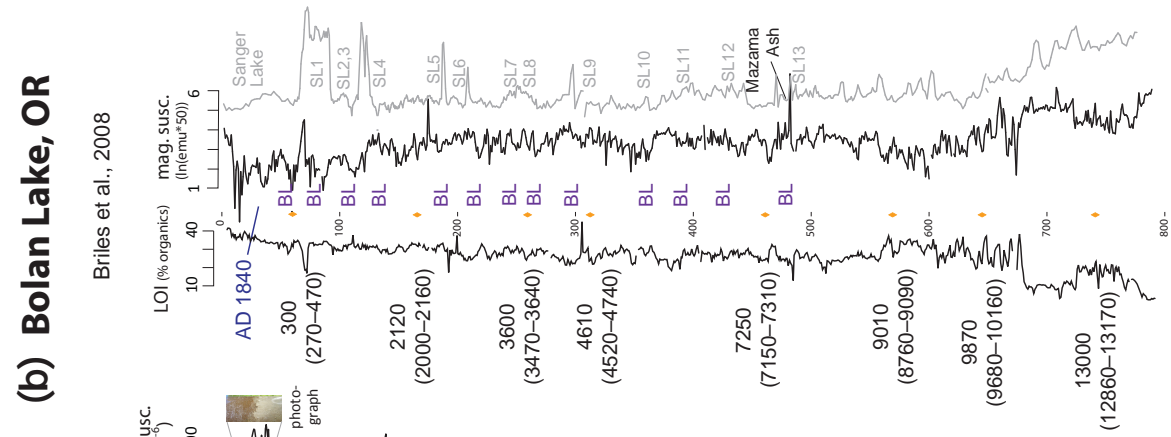

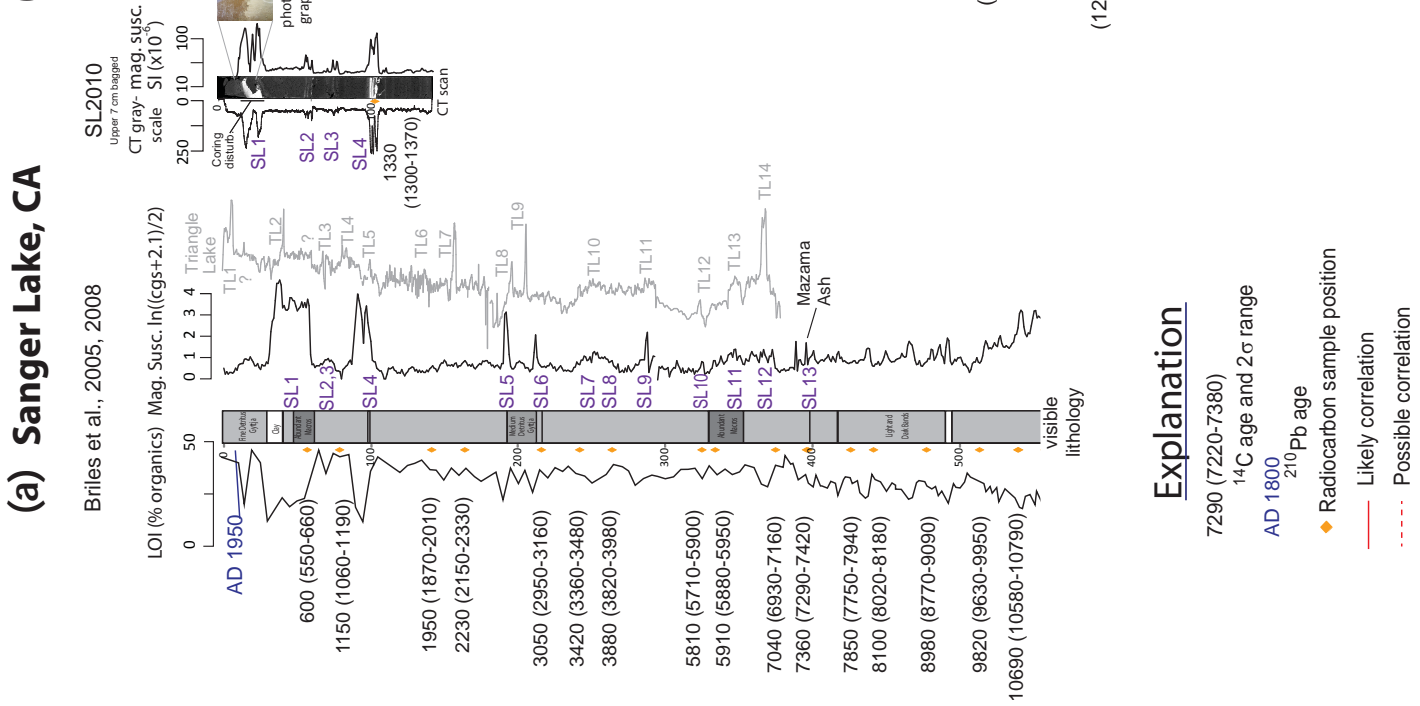

Fig. 2. Magnetic susceptibility records for the four sites discussed in this paper with AMS radiocarbon dates. Magnetic susceptibility was $\log$ transformed where indicated to minimize dominance by extreme values if needed. Radiocarbon dates were recalibrated from original published data using Calib 6.0; $2 \sigma$ ranges are shown in parentheses. (a) Sanger Lake, CA; (b) Bolan Lake, OR (with Sanger Lake magnetics shown in grey at right); (c) Upper Squaw Lake, OR; (d) Triangle Lake, OR (with Upper Squaw Lake magnetics shown in grey at right). Identified peaks used in this study are labeled here as SL, Sanger Lake; BL, Bolan Lake (without numbering as peaks are not clearly identifiable); USL, Upper Squaw Lake, and TL, Triangle Lake. 
between the midpoint of the sample and the base turbidite deposit (after accounting for erosion) using relevant sedimentation rates. Calibration of radiocarbon determinations from planktonic microfossils requires a reservoir-correction value $(\Delta R)$, representing the age of the carbon in the seawater in which the planktonic foraminifers were living. $\Delta R$ is a published, spatially varying value specific to west coast sites (Reimer and Reimer, 2001). Temporal variability in $\Delta \mathrm{R}$ also exists, but is not well known; however a correction was estimated and applied to the ages shown in Goldfinger et al. (2012). Finally, radiocarbon ages were combined using OxCal (Ramsey, 2001) in an attempt to narrow the range of estimates.

All radiocarbon dates from lake samples used in this paper result from radiocarbon analysis of terrestrial plant fragments. Samples were taken to provide chronological framework to a core, not to date an individual event. Plant fragments in lake sediment are detrital, and therefore existed as detritus for an unknown amount of time prior to burial. Rapidly degraded plant fragments (such as herbaceous leaves, stems and buds) were selected over those that degrade slowly (wood fragments, seeds, charcoal) when available. All radiocarbon ages from lake sediment presented in this paper are maximum limiting ages.

All lake and marine radiocarbon ages shown here are expressed in calendar years before present (1950), and were recalibrated from the original data using Calib 6.0 (http://calib. qub.ac.uk/calib). Radiocarbon ages are reported as median probability followed by the $2 \sigma$ range in parentheses. Values are rounded to the nearest $10 \mathrm{yr}$ for samples with standard deviations greater than $50 \mathrm{yr}$.

\section{Results}

\subsection{Preliminary identification of earthquake-triggered deposits}

Peaks in magnetic susceptibility above background levels were identified for each lake core. We have labelled each peak that meets our criteria with a lake abbreviation (SL: Sanger Lake, BL: Bolan Lake, USL: Upper Squaw Lake, TRI: Triangle Lake), and a number based on stratigraphic position of the layer (1 near the top of the core, increasing with time), except for at Bolan Lake where magnetic susceptibility does not have extreme values compared to background, and there were no visible layers described.

\subsection{Correlating deposits: inter-lake and marine-lake comparisons}

\subsubsection{Inter-lake correlations}

Figure 2 shows side by side comparisons of LOI, magnetic susceptibility, mapped visual layers, and age data for the four lake cores used in this study, with numbered disturbance events as previously described. There are common features in the sedimentary records from the spring-fed lakes (grey trace of Sanger Lake adjacent to the Bolan Lake record, Fig. 2b) from similar environments $20 \mathrm{~km}$ apart, as well as in the sedimentary records from the landslide-dammed lakes (grey trace of Upper Squaw Lake adjacent to the Triangle Lake record, Fig. 2d). Sanger Lake magnetic susceptibility was stretched to match two tie points: (1) the large magnetic susceptibility excursion (dated below the deposit at 600 cal yr BP) in Sanger Lake with the most likely correlative in Bolan (dated above the deposit at 300 calyrBP), and (2) the Mazama Ash datum in both cores, then linearly adjusted between those tie points where additional radiocarbon dates, ${ }^{210} \mathrm{~Pb}$, or ${ }^{137} \mathrm{Cs}$ provided more information. Upper Squaw Lake was tied to Triangle Lake using a single radiocarbon date for each core as shown on Fig. 2 d, and the first prominent pre-20th century magnetic susceptibility excursions in both records. The Upper Squaw Lake 20th century increase in sedimentation rate was adjusted to approximately reflect the same time range at Triangle Lake.

Sanger and Bolan lakes' magnetic susceptibility data are similar throughout. Sanger Lake core has 13 layers identified as peaks or variability above background levels. In some cases, magnetic susceptibility and organic content in both Sanger Lake and Bolan Lake cores show similar patterns, even where there are no individually identifiable layers (see, for example, the similar variability at around disturbance events SL11 and SL12 as compared to the correlated region in the Bolan Lake core). These sites are different in that the Sanger Lake record has larger excursions in magnetic susceptibility which are associated with thicker deposits as compared to Bolan Lake. For example, the upper metre of the Sanger Lake core has two large excursions in magnetic susceptibility, with values that are 3.5-4 times the background values (which are on a log scale) in the upper metre of core. This difference in expression may be a result of differences in sediment supply and sources at these sites. Both Bolan and Sanger lakes are predominantly spring fed with some seasonal overland input. Sanger Lake is different from Bolan Lake in that there is a landslide deposit upslope through which water flows just before entering the lake. Shaking during a great earthquake may release the fine sediment removed from water as it flowed through the slide. Although these records are very similar, it is difficult to determine any of the features in the Bolan Lake record are disturbance event deposits because there are no visible deposits to analyse (other than the Mazama Ash).

In contrast, Sanger and Upper Squaw lakes both have multiple disturbance event deposits throughout, although in this case Upper Squaw Lake has many additional, visible events that are not apparent in the Sanger Lake record. The new Sanger core provides more detail, and represents almost the same time period ( 0 to $\sim 1800$ calyr BP). A comparison of the new Sanger core with the Upper Squaw Lake core suggests SL 1-4 correlate to USL 2, 4, 5, 6 (Fig. 2e), although 
more radiocarbon ages are needed to confirm this relationship.

Sanger Lake and Triangle Lake have a similar number of magnetic susceptibility peaks over the past $\sim 6000 \mathrm{yr}$, however the LOI data for the Triangle Lake core do not show many peaks, unlike the LOI data for Sanger Lake (which may be a function of the thinner layers in the Triangle Lake core in combination with low resolution sampling). Tying event SL1 to TL2, and SL4 to TL5, then tying the records at 5900 calyr BP in both cores, shows the records are very similar, especially between 3000 and 6000 cal yr BP (Fig. 2a). Again, additional radiocarbon ages are needed to confirm these relationships.

Upper Squaw Lake and Triangle Lake, more than $240 \mathrm{~km}$ apart, also have similar features in their magnetic susceptibility records (Fig. 2d). The similarity of these records is interesting given the lack of visible structure in the Triangle Lake core as compared to the visibly complex structure of the Upper Squaw Lake core (as shown in the photographs and CT scans at the bottom of Fig. 2c and d). The largest excursions in Triangle Lake magnetic susceptibility are associated with visibly lighter silt bands, whereas the largest excursions in the Upper Squaw Lake magnetic susceptibility are associated with the thickest massive deposits which are more mineral-rich as compared to surrounding sediment. Between these thick deposits are laminations of silty gyttja occurring much more frequently than could be explained by Cascadia subduction zone earthquakes alone, and a possible explanation is that the Upper Squaw Lake includes records of watershed events in addition to Cascadia's great earthquakes.

Another interesting feature of these records is that at both sites there is an excursion in magnetic susceptibility (TL1 and USL1) during an interval that appears to be younger than the most recent Cascadia earthquake, known to have occurred in $1700 \mathrm{AD}$ (Atwater, 2005; most likely represented in these cores by USL3 and TL2). The timing of this event is currently under investigation, but an age of roughly $1900 \mathrm{AD}$ is supported by the position of this event between the coincident shift in LOI at Upper Squaw Lake that has been attributed to land clearing that began in that area around the mid 1800s (Colombaroli and Gavin, 2010) and the 1964 137Cs peak. This deposit may have been the result of a magnitude $\sim 7.3$ earthquake of $1873 \mathrm{AD}$ that occurred near the coast of the Oregon/California border (Bakun, 2000).

\subsubsection{Lake-marine correlations}

Figure 3 shows a comparison of physical property and radiocarbon data from Bolan, Sanger, Upper Squaw, and Triangle lakes plotted with physical property data from cores at marine sites Rogue Apron, Smith Apron, and Hydrate Ridge basin all in deep water near the Cascadia plate boundary. We have scaled the vertical dimension to match approximate age horizons using radiocarbon age control to compare the stratigraphy between lake sites, as well as to compare to turbidite cores offshore from approximately the same latitude.

We have identified seven disturbance event deposits in the Sanger Lake sediment core based on visual characteristics, magnetic susceptibility and LOI between 200 and 4000 cal yr BP, and Bolan Lake has similar variability, but no clearly identifiable disturbance event deposits. Offshore, the Rogue Apron core has nine significant turbidites in the same time range. Upper Squaw Lake has seven significant disturbance event deposits over the past $\sim 1600 \mathrm{yr}$, about the same number of turbidites found at the Rogue and Smith Apron offshore sites. Although radiocarbon ages in the lake cores were not acquired to determine the time of disturbance resulting from the deposits described in this paper, they provide enough age control to show the disturbances occurred at similar times in lakes as compared to the offshore turbidites. Figure 3 shows that offshore events T2, T3, T4, T5, T6, T7, T8, and T9 appear to have good correlatives at Sanger and Bolan lakes. Upper Squaw Lake also has ages or event ages that closely match offshore cores at Rogue and Smith Aprons for offshore events T2, T3, T4, and T5 (Fig. 3).

We also find a similar sequence of disturbance events in both the lake and offshore sediment cores (Fig. 3). For example, one of the thicker offshore turbidites is marine event $\mathrm{T} 5$, and the most likely correlative in the Sanger Lake core is also a thicker deposit with a prominent magnetic susceptibility signature (also seen in the Bolan Lake core although the magnetic susceptibility sequence in this core is much less prominent). In the Upper Squaw Lake core the sequence appears more complex, with multiple peaks in magnetic susceptibility, however this complexity is similar to variability seen in the likely correlative in the offshore Smith Apron core (M9907-33TC). Similarities also exist between marine and lake cores for marine events $\mathrm{T} 2$ and $\mathrm{T} 3$, and the peaks in Bolan and Sanger lakes that appear to correlate with Rogue Apron deposits T6, T7, T8 and T9, however additional age control is needed to confirm these relationships.

The lake cores have a series of thin deposits between the major units in similar stratigraphic positions as the mud turbidites described in Goldfinger et al. (2013). For example, offshore cores consistently have three thin events between $\mathrm{T} 5$ and T6, known as T5a, T5b, and T5c. These events occupy $\mathrm{a} \sim 1000 \mathrm{yr}$ interval of time found at all offshore sites and many onshore paleoseismic sites. Bolan and Sanger lakes also contain a similar gap between major events which are occupied by three deposits in the Bolan Lake record and three or four deposits in the Sanger Lake record. Ages for several of these smaller events from these two lakes are compatible with ages for T5b and T5c offshore. In Upper Squaw Lake, a compatible age was obtained from near the base of the core for the potential correlative of offshore event T5a. Other potential correlatives for the offshore mud turbidites are seen in Upper Squaw Lake for events T2a and T2b; in Sanger and Bolan lakes for T6a, T7a (Bolan only), and T8a and T8b, though further work on these smaller events is required. 


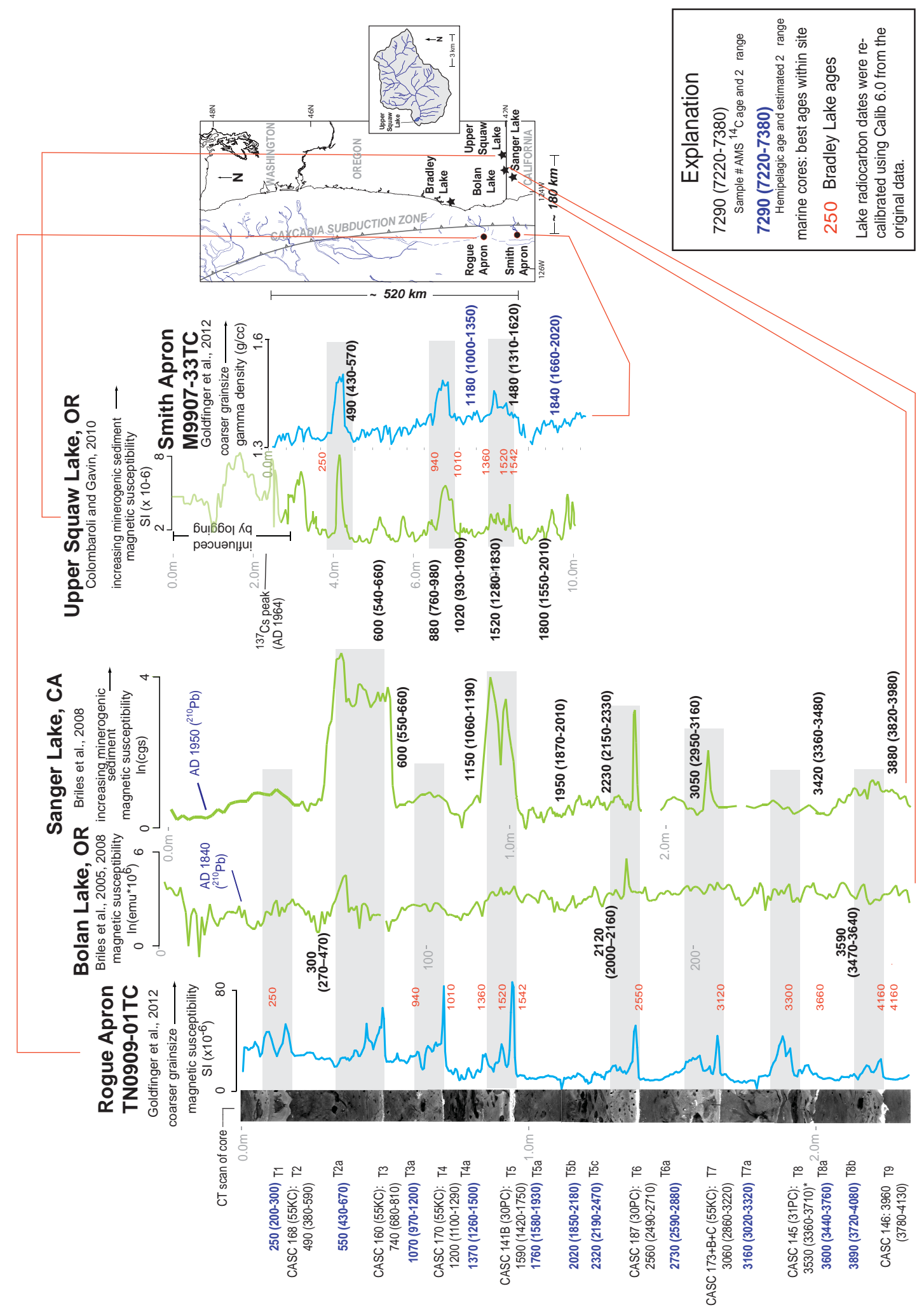

Fig. 3. Tentative correlation diagram including Upper Squaw and Sanger lakes, and offshore cores TN0909-01PC/TC at Rogue Apron, and M9907-33TC at Smith Apron. These cores, at roughly similar latitudes, also have a similar sequence of primary stratigraphy, and compatible age control (with $2 \sigma$ ranges in parentheses). The lake data is log normalized and "flattened" to the offshore core, matching ages control and major event bases to account for differences in sedimentation rate. Bradley Lake tsunami disturbance event deposit dates are shown on this figure in red. 


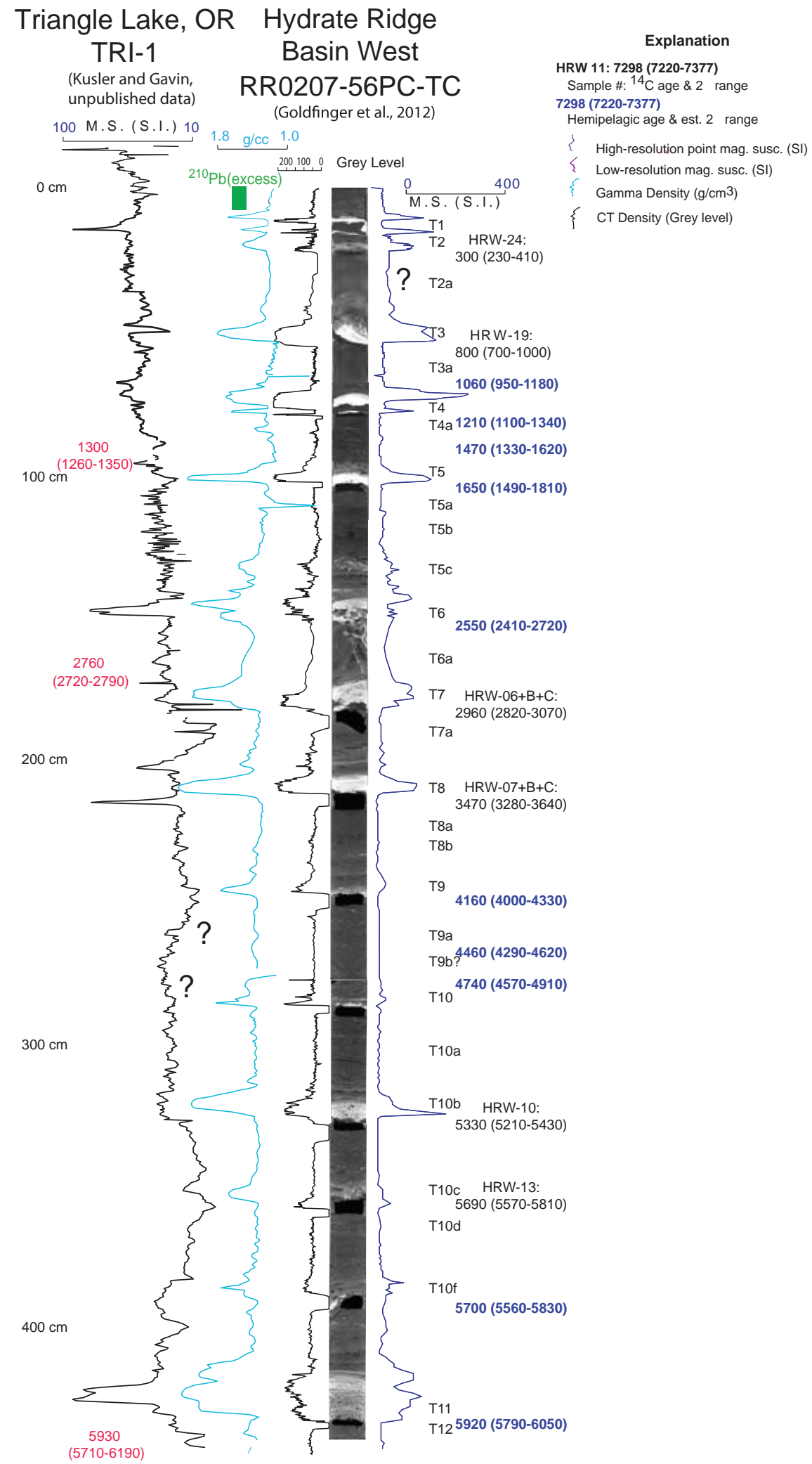

Fig. 4. Preliminary correlation diagram including Triangle Lake core TRI-1, and offshore core RR0207-56PC/TC. These cores, at roughly similar latitudes, have a similar sequence of primary stratigraphy, though at present only three ages exist at Triangle Lake. Hydrate Ridge serves as the offshore control site, as it is a very isolated lower slope basin with no possible input of terrestrial sediment other than hemipelagic. Note that the Triangle Lake magnetic susceptibility data is log-normalized and "flattened" to the Hydrate Ridge core. Flattening is used to position radiocarbon ages in one core to the most similar ages in another core, compensating for differences in sedimentation rates. 
Triangle Lake also contains a series of Holocene sediment deposits (Fig. 4). As with Bolan, Sanger, and Upper Squaw lakes, we found a good correspondence between the number and sequence of terrigenous events in the lake and turbidite sequences offshore. The largest event in the Triangle Lake core is dated at 5930 (5710-6190), and is larger than the others in that core, with two separate magnetic peaks. Similarly, the largest Cascadia event T11 (at all Cascadia sites) is also massive with two magnetic susceptibility peaks and has an identical age. We find good potential correlatives for offshore events T1, T2, T3, T4, T6, T8, T10b, T10c, T10f, and $\mathrm{T} 11$, while equivalents of offshore $\mathrm{T} 5, \mathrm{~T} 9$ and $\mathrm{T} 10$ are weak in the Triangle Lake core. Particularly striking similarities in the vertical magnetic profiles include T3, T8, T10c, and T11. As with Bolan, Sanger, and Upper Squaw lakes, we find potential correlatives for the thinner series of mostly mud turbidites found at the latitude of Hydrate Ridge, including T2a, T3a, T4a, T5a, T5b, T5c, T6a, T6b (not observed at Hydrate Ridge, but at sites further south), T7a, T8a, T8b, T9a, T9b, T0a, T10b, T10c, T10d, and T10f. Although further work is needed to identify disturbance deposits in these lake cores, the similarities between magnetic susceptibility records is strong evidence for synchroneity.

\subsection{Other Cascadia lakes and coastal inlets}

Bradley Lake is a southern Oregon coastal lake which formed as a migrating sand dune blocked China Creek. Bradley Lake contains a tsunami record of marine sands that inundated the lake. Kelsey et al. (2005) established the requirements for such inundation in detail, and they concluded that the tsunami record there was attributable to local, rather than distant, tsunami. The Bradley Lake record exhibits a greater number of events through time than nearby estuary records, including 12 events that require a tsunami height of $>5.5 \mathrm{~m}$ to reach the lake (Kelsey et al., 2005).

Some of the Bradley Lake disturbance event deposits are likely turbidites; these are denoted as disturbance events 3 , 14, 15, and 16 in Kelsey et al. (2005). These events do not show evidence linking them to marine incursions and are represented instead by deposition of lake-wide, organic-rich mud layers the authors attribute to earthquake-triggered wall failures. These four events have potential offshore temporal correlatives of T4, T9b, T10c, and T12 respectively. Two of these events (T9b and T10c) are smaller mud turbidites offshore with limited spatial extent. One of them, T12, is ubiquitously thin in all offshore cores, and the fourth, T4 is an event of typically modest thickness and mass at most offshore sites. The ages for the Bradley Lake disturbance event deposits (in red; Fig. 3) are generally consistent with correlations between marine and lacustrine records, though with one significant exception. Three disturbance event deposits occur between 1350 and 1560 calyr BP, during which time there were two events offshore, T4a and T5. During this time we also observe multiple magnetic peaks in Sanger and Up- per Squaw lakes. It may be that the two main pulses of offshore event T5, a characteristic of T5 at numerous sites, may represent two events resolving this discrepancy.

Bull Run Lake $\left(45^{\circ} 27^{\prime} 20^{\prime \prime} \mathrm{N}, 121^{\circ} 50^{\prime} 0^{\prime \prime} \mathrm{W}\right)$ is a 189 ha, $\sim 80 \mathrm{~m}$ deep, landslide-dammed and/or glacial cirque lake with a $9.1 \mathrm{~km}^{2}$ drainage area located at an elevation of $963 \mathrm{~m}$ on the northwest flank of Mt. Hood located $167 \mathrm{~km}$ from the coast. Cores extracted from the lake reveal a series of deposits with bulk density excursions that terminates at a large event that includes the Mazama Ash (Raymond, 1983; unpublished data). Although there are similarities in timing as compared to the marine turbidite record, interpreting these features as seismogenic is speculative, as a result of the coarse resolution of bulk density data and imprecise age control resulting from the analysis of bulk sediment used in this study.

Lake Washington $\left(47^{\circ} 36^{\prime} 34^{\prime \prime} \mathrm{N}, 122^{\circ} 15^{\prime} 34^{\prime \prime} \mathrm{W}\right)$ is a large $(22 \mathrm{~km} \times 5 \mathrm{~km})$, deep $(65 \mathrm{~m})$, steep-sided lake formed in a glacially carved basin in Puget Sound, Washington, USA. Side-scan images show numerous sediment slumps and debris flows, and high-resolution seismic profiles show large retrogressive slope failures. Sediment cores from throughout the lake show sedimentary deposits with magnetic susceptibility signatures that can be correlated throughout the lake and which have been interpreted as a result of shakinginduced sediment failures. Although one event (event E) was attributed to a large earthquake (dated to 900-930 AD) on the Seattle Fault (the strands of which underlie Lake Washington), the 300-500 yr recurrence interval, and temporal relationship to subduction zone events represented in other records such as coastal subsidence stratigraphy and tsunami deposits from coastal Washington, suggest the lake sediment also records subduction zone earthquakes (Karlin and Abella, 1992, 1996; Karlin et al., 2004).

Cores from Effingham Inlet, a fjord off Vancouver Island, British Columbia, Canada (Dallimore et al., 2005, 2009), as well as Saanich Inlet contain seismogenic submarine debrisflow deposits, with physical properties that show a striking relationship in timing and characteristics to offshore turbidites. Dallimore et al. $(2005,2009)$ interpret a number of seismites in these cores, based on the distinct wall rock signature from the fjord walls, and the fining upward distinctive turbidite signature, as compared to the background sedimentation which is more climate related. They identified and dated the deposit from the 1946 Vancouver Island $M_{\mathrm{w}}=7.2$ earthquake, and a number of other Holocene seismites. Physical property "wiggle match" correlations of six of the Effingham Inlet events and events of compatible age in our Cascadia Channel cores suggest these archives record the same events (Goldfinger et al., 2012). We show magnetic and density traces, and radiocarbon ages for Effingham and Cascadia Channel cores for these events (Fig. 5). A strong stratigraphic signature common to both nearshore and offshore cores is apparent, as well as a correspondence of relative thickness of the events downcore, again, supported by compatible age 
control. We believe that this evidence lends strong support to an earthquake "signature" as the common link between these fjord, lake and offshore cores.

Cores collected in Saanich Inlet, on the eastern side of Vancouver Island contain a record of debris-flow events interspersed with varved sedimentation similar to that found in Effingham Inlet (Blais-Stevens and Clague, 2001; BlaisStevens et al., 2011). Cores from ODP leg 169 and older cores established a record of synchronous deposition of debris-flow deposits at sites separated by several kilometres. Saanich and Effingham cores both have potential time correlatives for a number of plate boundary earthquakes recorded by onshore and offshore palaeoseismic data during the Holocene except T8, T13, and T14, which may be represented at Saanich, but not Effingham. Events T15, T16, T17, and T18 may be present at Effingham, but data are not available for Saanich. There are a greater number of debrisflow events than present in the land or marine palaeoseismic records from other sites. These events generally are thinner deposits, suggesting smaller earthquakes or nonseismic sources. Given the known record of at least one debris-flow deposit attributable to a crustal earthquake, it is reasonable to assume that many of the smaller events originate from crustal earthquake sources (Blais-Stevens et al., 2011).

\section{Discussion - do lake sediments record great Cascadia earthquakes?}

\subsection{Are there turbidites in Cascadia lake sediments?}

The newly acquired core (2010) from Sanger Lake (SL2010) was used to investigate the possibility that gravity flow deposits are contained within lake sediments in a time range that may correlate to Cascadia marine event T5. CT imagery of this core shows multiple dense events in the core, which appear to be the same events from the upper $110 \mathrm{~cm}$ of the published Sanger Lake core. The region of the core that may correlate to Cascadia marine event T5 (dated at 1590 (1420-1750) cal yr BP) based on comparison to the original published core was identified as a visible silt and clay layer with very low organic content from $80-105 \mathrm{~cm}$. This section was not dated below the event as with the marine turbidite event, but rather was bracketed in time by a date of 1150 (1061-1190) cal yr BP approximately $20 \mathrm{~cm}$ above the event, and 1950 (1870-2010) cal yr BP about $30 \mathrm{~cm}$ below the event in the published core.

A sharp contact defines the base of the unit, which occurs at about $110.5 \mathrm{~cm}$, between fine detritus gyttja below and a $\sim 1 \mathrm{~cm}$ medium- to coarse-grained sand above that ends in a fine-grained greyish-brown silty-clay layer at about $104 \mathrm{~cm}$ (Fig. 7a). This unit is actually comprised of two fining upward sequences showing grain size and compositional changes as follows. Sequence 1: medium- to coarse-grained black and white sand with a mean grain size of about $300 \mathrm{~cm}$ with little organic material. This is overlain by a $1.5 \mathrm{~cm}$ thick coarse woody debris layer and very little terrigenous grains (mean grain size of about $250 \mu \mathrm{m}$ ). This layer is topped by a mixed terrigenous and medium-fine plant debris which is capped by a thin layer of silt and clay ending at about $107.5 \mathrm{~cm}$. Fining upward in grain size is confirmed by grainsize analysis which show mean grain size decreasing from about $320 \mu \mathrm{m}$ at $108.5 \mathrm{~cm}$, to $275 \mu \mathrm{m}$ at about $108 \mathrm{~cm}$, then to about $125 \mu \mathrm{m}$ at $107.5 \mathrm{~cm}$. Sequence 2: mean grain size jumps up to about $260 \mu \mathrm{m}$, with medium-fine woody debris, then fines again to the lowest values in the sequence of about $30 \mu \mathrm{m}$, which is the location of the $\sim 1 \mathrm{~cm}$ thick greyishbrown silty clay layer.

Magnetic susceptibility data acquired at $0.5 \mathrm{~cm}$ intervals are compared to the photograph, CT scan and grain-size data shown in Fig. 7a. Magnetic susceptibility values are moderately low before rising significantly at the contact between background sediment and the medium-coarse sand at the beginning of sequence 1 . Magnetic susceptibility values then drop through a layer of coarse woody debris. Magnetic susceptibility again rises abruptly then more slowly drops as grain size decreases to the fine silt and clay layer at the end of sequence 1. Magnetic susceptibility increases only slightly again at the beginning of sequence 2 with the increase in grain size at about $107.5 \mathrm{~cm}$, likely a result of the more abundant plant material within this layer, then ramps down as grain size decreases somewhat through the clay and silt layer, returning to background levels before reaching the fine detritus gyttja at the end of sequence 2 . Although plant debris is not as common in marine turbidites, they have been documented, most notably from cores from the Astoria Fan (Nelson, 1976) where plant debris was found in the upper Bouma Td.

The correlation of features and timing of seismogenic deposits at the marine Rogue Apron site, tsunami data from Bradley Lake and Sanger Lake support the interpretation that Sanger Lake sediments contain a record of subduction zone earthquakes. Each sequence appears to be a separate turbidite deposit, with wood and other plant debris falling out of suspension with terrigenous grains, presumably in order of density. Magnetic susceptibility values both reflect grain size and the relative amount of organic material to terrigenous clastics in the sediment. For small lakes with organic-rich sediment, this means that interpretation of the magnetic susceptibility event "fingerprint" (as well as gamma density and CT scans) must take into account the presence of plant macrofossil layers and changes in organic content to avoid misinterpreting the data. Alternatively, lake sediments with low organic content, such as the landslide-dammed lakes in this study, would produce physical property data less likely to be influenced by layers of plant debris. With this interpretation of the stratigraphic sequences and associated data from Sanger Lake, we can compare this unit to marine event T5 in Rogue core M9907-31PC (Fig. 7b). Similarities support the interpretation of marine event T5 as two events closely 

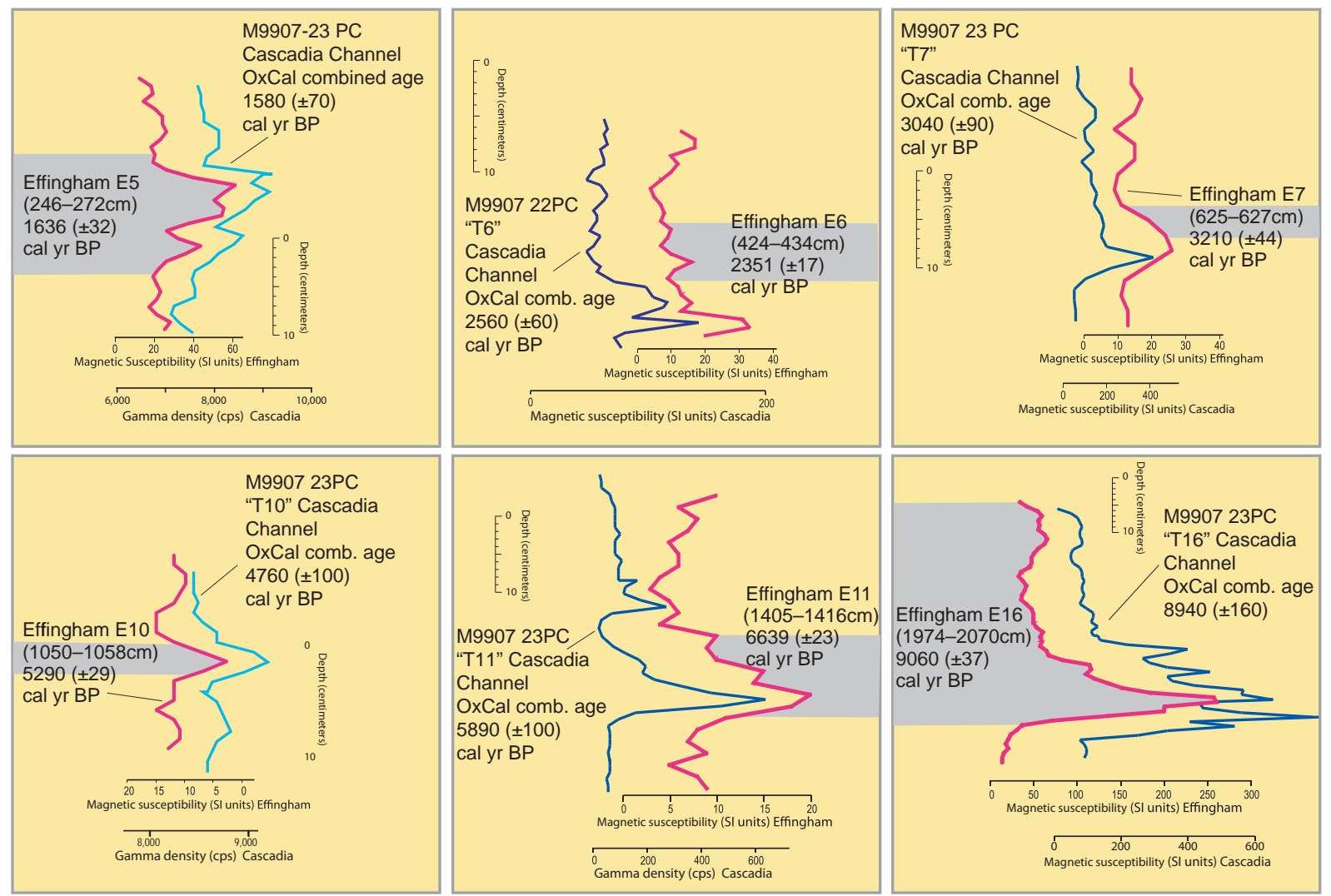

Fig. 5. Preliminary correlations between Cascadia Channel core M9907-23PC and core MD02-2494 from Effingham Inlet, western Vancouver Island, Canada. Each plot shows the magnetic-susceptibility record (blue) from an Effingham Inlet (inner basin) turbidite, and a magnetic-susceptibility or gamma-density record from our 1999 cores in Cascadia Channel (in purple). These events were interpreted as seismites by Dallimore et al. (2005), Thomson and others (2005) based on the wall-rock signature from the adjacent fiord walls (shown in grey) and by comparison to the historical turbidite triggered by the1946 Vancouver Island earthquake. The records show a striking similarity in general size, number of sandy pulses (magnetic and density peaks) and in some cases, detailed trends. Radiocarbon ages also are first-order compatible, but have separations of 100-200 yr in some cases. The combined age data and stratigraphic correlation suggest that the Effingham turbidites and Cascadia Basin turbidite signatures are recording the same earthquakes. Effingham data from Dallimore et al. (2009).

spaced in time, as suggested by the Bradley Lake tsunami data.

The Upper Squaw Lake record contains hundreds of thin layers that are too numerous for them to all be earthquaketriggered deposits, and likely represent watershed events, whereas the thickest layers correlate to the offshore turbidite record and are more likely to be seismogenic turbidites. The four-fold increase in terrigenous input into the lake over the past century (recorded in the upper $2.8 \mathrm{~m}$ of the core) as compared to pre-20th century levels indicates the sensitivity of this site to changes in the watershed. The magnetic susceptibility record shows variability in sedimentation rate and magnetic susceptibility which track the known history of landuse changes and forest fire within the drainage (Colombaroli and Gavin, 2010). Other events such as fire are likely preserved in the sedimentary record at this site, as suggested by a comparison of charcoal peaks and magnetic susceptibility showing that at Upper Squaw Lake, charcoal peaks lead mag- netic susceptibility peaks slightly (mainly after 1200 AD) as would be expected if a fire-denuded landscape was subsequently eroded. Charcoal abundance is expected to drop after its initial peak; however, charcoal abundance continues to remain high throughout the turbidite deposits.

We suggest the apparent correlation between lakes, and between lakes and the offshore cores, is due to a common trigger mechanism, subduction zone earthquakes. We suggest that the mechanism that best fits the data would involve strong shaking that dislodges, liquefies, and entrains sediment producing gravity flows in the lake which result in fining upward turbidite or homogenite deposits - the same mechanism that has been interpreted to produce marine turbidite deposits (Fig. 6). Anecdotal evidence, side-scan images and chirp profiles of lake side-walls and interpretations of lacustrine archives from multiple settings have shown that earthquakes can remobilize sediment within a lake producing turbidite deposits. One of the most relevant studies is the 

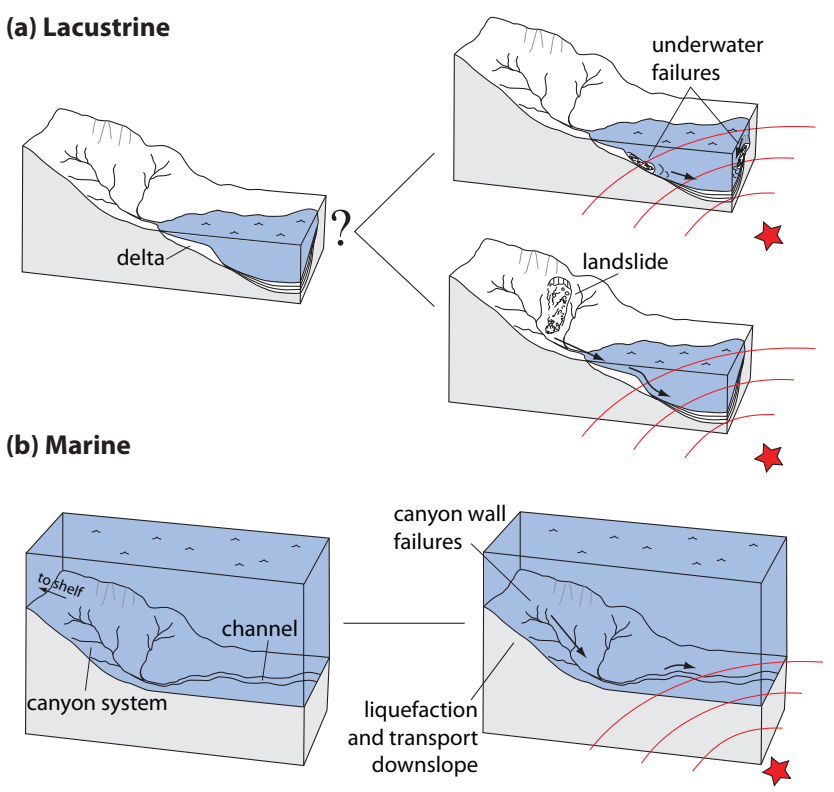

Fig. 6. Schematic showing a comparison between (a) two possible scenarios for mechanisms to explain seismogenic terrigenous layers in lake sediments. Shaking from a subduction zone earthquake will either dislodge material internal to the lake (above) or external to the lake (below). This creates a mixture denser than the surrounding water, which is then transported as a gravity flow producing a turbidite deposit with fining upward structure. Sediment transported into the lake from the drainage is unlikely to produce a gravity flow deposit and would have inverse then normal grading and thin from the source. (b) Our current interpretation of the mechanism creating seismogenic turbidite deposits in marine sediments. Shaking dislodges and entrains sediment from shallower water creating density flows which are then transported to the abyssal plain via submarine channels and as sheet flows where sediments are deposited as fining upward sequences.

investigation of anomalous silt layers within otherwise organic rich gyttja sediment from lakes in eastern Canada. The ages of the silt layers support the notion that they resulted from five historic earthquakes on nearby crustal faults (Doig, 1986, 1991).

The most common explanation for the presence of silt layers in sediment from Oregon and Washington lakes has been increased sediment transport from sources external to the lake, however subsequent investigations suggests these deposits result from shaking-induced failures. The idea that shaking causes sediment entrainment internal to the lake came from visual observations of "whitening" of Lake Kipawa, Quebec, during the 1935 Temiskaming earthquake, which was not likely due to stream input (Hodgson, 1936a, b; Doig, 1990). The silt layers are formed during differential settling as a result of grain size and density variations in the redistributed sediment. Doughty et al. (2010) present further evidence of lake-wall failures using chirp seismic profiles of the lake bed that show that sediment was removed from the sides of the lake and redeposited into the deepest part of the lake. Similar deposits have been documented in the Dead Sea (Marco et al., 1996; Migowski et al., 2004), and these events have shown a strong linkage between the historical earthquake intensity, the thickness of seismites and epicentral distance (Migowski et al., 2004; Strasser et al., 2006, 2007, 2011). We suggest that earthquake records from Cascadia inland lakes have the same potential to reconstruct earthquake chronologies and possibly even provide evidence as to the degree of shaking that will be experienced inland where populations are highest.

\section{Conclusions}

Core magnetic susceptibility and radiocarbon data were compared among Sanger, Bolan, Upper Squaw and Triangle lakes in the southern and central Cascadia forearc, and to offshore cores known to contain a turbidite palaeoseismic record. Sanger and Bolan lakes, both predominantly spring-fed cirque lakes, and Triangle and Upper Squaw lakes, both landslide-dammed lakes, contain stratigraphic sequences with magnetic susceptibility excursions that are associated with terrigenous deposits with lower organic content as compared to background sedimentation. Upper Squaw Lake also records thin layers too numerous to have been caused by subduction zone earthquakes, and are therefore likely to record both earthquakes and watershed events.

We identified possible seismogenic turbidite deposits based on visible features in the cores and physical property data (magnetic susceptibility and LOI) to be used to correlate between lakes, and to the offshore seismogenic turbidite record to test for synchronous triggering. Radiocarbon ages were acquired for lake deposits for a general chronology not to date specific deposits (unlike the marine sediment cores), however enough age control and similarity exists between lake records and lake and offshore records to support synchronous triggering. There are similar numbers of events in marine and lake settings, and the most dominant margin-wide deposits are also dominant in the lake records.

Evaluated disturbance event deposits from Sanger Lake have sharp bases and fining upward grain size profiles, sometimes with multiple stacked units within a sequence of turbidites. These deposits have the characteristics of linked debrites as they sometimes have a basal unit containing coarse grains and woody debris that appears to be a debrite, followed by normally graded sediment. There do not appear to be any linked debrites in the landslide-dammed lakes. The deposits from these lakes are graded, but are less dense, and more organic rich at the base, then become more mineral rich with settling with an associated peak in magnetic susceptibility. A silt- and clay-rich cap is sometimes followed by a final layer of very fine organic-rich sediment almost devoid of clastics. 


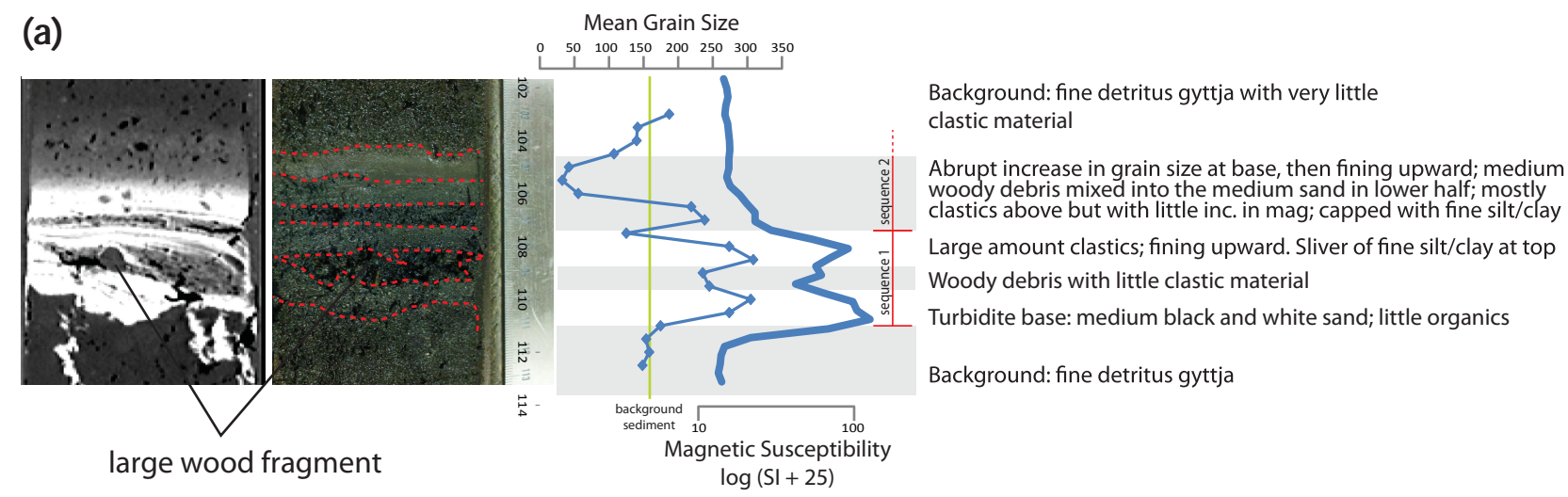

(b)

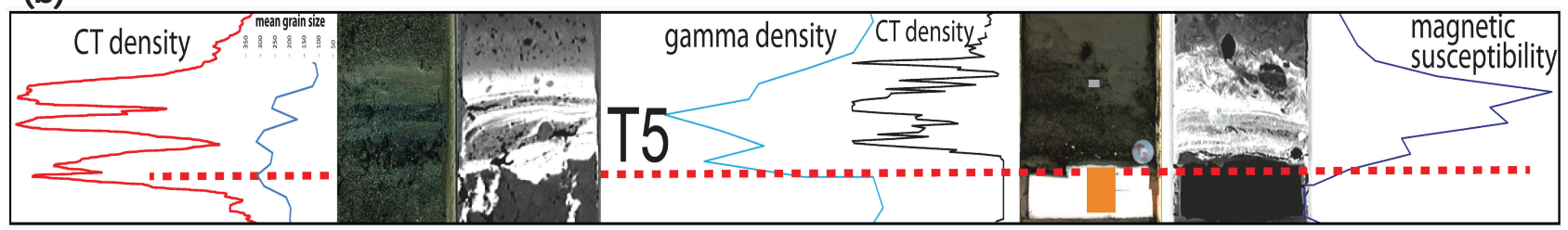

Fig. 7. (a) CT scan, photograph, mean grain size, magnetic susceptibility and composition information showing the structure of a stratigraphic unit from approximately $1500 \mathrm{calyr}$ BP in the new Sanger Lake core (SL2010). Results suggest two fining upward sequences, with fine silt and clay caps (which take time to settle from the water column). The presence of high concentrations of woody debris alters the magnetic susceptibility and density records of this sequence. (b) Based on similarities in physical properties and event timing, this event is thought to correlate to marine event T5. Both data sets support the idea that T5 may be a composite of two events closely spaced in time, which is supported by the presence of two deposits from the same time at Bradley Lake, which were determined to be $\sim 20-40$ yr apart based on the evaluation of varves separating the two events (Goldfinger et al., 2012).

Each lake setting is different, however, underscoring the need to understand the depositional processes within each lake prior to interpretation of sediment properties. For example, the presence of an organic-rich layer (such as woody debris layer) without clastics would have a magnetic susceptibility signature that would look anomalously low, suggesting a division (representing time) between two deposits, which may not be true. Because the deposits, even when complex, show evidence of instantaneous deposition (graded deposits, where clastics and organics separate during settling), supporting they were formed internal to the lake. The observed stratigraphy is most consistent with turbidite deposition from shaking within the lake, followed by differential settling of suspended material, analogous to the mechanism generating offshore marine turbidite deposits. More radiocarbon ages and detailed sedimentological analyses are needed to confirm correlations.

Detailed analysis of a representative event from Sanger Lake core (SL2010) suggests we have much to learn about great earthquakes through the study of lake palaeoseismology in Cascadia. The sequence begins with a sharp base fining upward, with characteristics that are very similar to the inferred correlative, marine event T5 dated at 1590 (14201750) cal yr BP in an offshore Rogue Apron core (M990730PC). Both lake and offshore sequences have features suggesting either a two sequence event, or two events closely spaced in time, which is supported by tsunami evidence at Bradley Lake (Kelsey et al., 2005).

The similarities between downcore magnetic susceptibility and associated radiocarbon data from both lake and marine cores over great distances and multiple depositional environments supports synchroneity and therefore earthquaketriggering. Lithologic characteristics of the disturbance event deposits suggest instantaneous deposition, and include many of the features of turbidites found in the marine record with some differences based on sediment supply and setting. The presence of earthquake-triggered deposits in forearc lakes may provide important information useful for hazard assessment from the coast inland to more populated areas. In addition, the analysis of these deposits from lakes throughout Cascadia maybe provide insight as to subduction zone characteristics, such as rupture lengths and segmentation.

Acknowledgements. We thank Amy Garrett for grain-size analysis and acquisition of magnetic susceptibility data for the 2010 Sanger Lake core, and Steve Galer for assistance with correlations. Richard Raymond provided his unpublished $\mathrm{PhD}$ thesis and data. We thank Richard Boettcher, who analysed and picked planktic foraminifera, and Michaele Kashgarian and John Southon for running most AMS radiocarbon analyses and for their assistance with many radiocarbon issues. We thank the officers and crews of the R/V Melville, $\mathrm{R} / \mathrm{V}$ Thompson, and R/V Revelle, who provided excellent ship handling 
and coring logistics for the field work. The coring techniques of Pete Kalk, Chris Moser, Bob Wilson and Chuen-Chi "Charles" Liu provided the marine piston cores that are necessary for palaeoseismic analysis. We also thank Steve Galer, Morgan Erhardt, Bran Black, Jeff Beeson, Tim Kane Amy Garrett and Jason Patton for thoughtful comments, help with data acquisition, analysis, graphics and field assistance.

The initial funding for this study was provided by the Coastal and Marine Geology Team of the US Geological Survey. The primary funding for field work and subsequent research has been provided by NSF Awards EAR 9803081 EAR-0001074, EAR-0107120, EAR-0440427 and OCE-0550843 (reservoir model development) and OCE 0850931 (2009 cruise). US Geological Survey substantially supported the work through Cooperative Agreements 6-7440-4790, 98HQAG2206 and 99HQAG0192; and US Geological Survey National Earthquake Hazard Reduction Program grants 02HQGR0019, 03HQGR0037, 06HQGR0149, 07HQGR0064 to Goldfinger, and 02HQGR0043, 03HQGR0006, 06HQGR0020 to Nelson. The American Chemical Society awarded support to PhD student Joel Johnson for core collection and analysis at Hydrate Ridge under ACS PRF 37688-AC8. The authors wish to thank the reviewers, A. R. Nelson and an anonymous reviewer, for their very detailed and thoughtful comments on this manuscript.

Edited by: C. H. Nelson

Reviewed by: A. R. Nelson and one anonymous referee

\section{References}

Abdeldayem, A. L., Ikehara, K., and Yamazaki, T.: Flow path of the 1993 Hokkaido-Nansei-oki earthquake seismic turbidite, southern margin of the Japan sea north basin, inferred from anisotropy of magnetic susceptibility, Geophys. J. Int., 157, 15-24, 2004.

Adams, J.: Contemporary uplift and erosion of the Southern Alps, New Zealand, Bull. Geol. Soc. Am., 91, 1-114, 1980.

Adams, J.: Active deformation of the Pacific Northwest continental margin, Tectonics, 3, 449-472, 1984.

Adams, J.: Paleoseismicity of the Cascadia subduction zoneEvidence from turbidites off the Oregon-Washington margin, Tectonics, 9, 569-583, 1990.

Alexander, J. and Morris, S.: Observations on experimental, nonchannelized, high-concentration turbidity currents and variations in deposits around obstacles, J. Sed. Res., A64, 899-909, 1994.

Aleotti, P.: A warning system of rainfall-induced shallow failure, Eng. Geology, 73, 247-265, 2004

Amy, L. A., McCaffrey, W. D., and Kneller, B. C.: The influence of a lateral basin-slope on the depositional patterns of natural and experimental turbidity currents, in: Deep-Water Sedimentation in the Alpine Basin of SE France: New Perspectives on the Grés d'Annot and Related Systems, edited by: Joseph, P. and Lomas, S. A., Special Publication-Geological Society of London, 221, 311-330, 2004.

Anastasakis, G. C. and Piper, D. J. W.: The character of seismoturbidites in the S-1 sapropel, Zakinthos and Strofadhes basins, Greece, Sedimentology, 38, 717-733, 1991.

Arnaud, F., Lignier, V., Revel, M., Desmet, M., Beck, C., Pourchet, M., Charlet, F., Trentesaux, A., and Tribovillard, N.: Flood and earthquake disturbance of $210 \mathrm{~Pb}$ geochronology (Lake Anterne, NW Alps), Terra Nova, 14, 225-232, 2002.
Arnaud, F., Magand, O., Chapron, E., Bertrand, S., Boës, X., Charlet, F., and Mélières, M.-A.: Radionuclide dating $\left({ }^{210} \mathrm{~Pb}\right.$, ${ }^{137} \mathrm{Cs},{ }^{241} \mathrm{Am}$ ) of recent lake sediments in a highly active geodynamic setting (Lakes Puyehue and Icalma-Chilean Lake District), Sci. Total Environ., 366, 837-850, 2006.

Atwater, B. F.: Evidence for great Holocene earthquakes along the outer coast of Washington State, Science, 236, 942-944, 1987.

Atwater, B. F., Musumi-Rokkaku, S., Satake, K., Tsuji, Y., Ueda, K., and Yamaguchi, D. K.: The orphan tsunami of 1700: Japanese clues to a parent earthquake in North America, US Geol. Surv. Prof. Paper, 1707, 133 pp., 2005.

Beck, C.: Late Quaternary lacustrine paleo-seismic archives in north-western Alps: Examples of earthquake-origin assessment of sedimentary disturbances, Earth-Sci. Rev., 96, 327-344, 2009.

Bertrand, S., F. Charlet, E. Chapron, N. Fagel, M., De Batist, Reconstruction of the Holocene seismotectonic activity of the Southern Andes from seismites recorded in Lago Icalma, Chile, $39^{\circ}$ S, Palaeogeogr. Palaeocl., 259, 301-322, 2008.

Blais-Stevens, A. and Clague, J. J.: Paleoseismic signature in late Holocene sediment cores from Saanich Inlet, British Columbia, Mar. Geol., 175, 131-148, 2001.

Blais-Stevens, A., Rogers, G. C., and Clague, J. J.: A Revised Earthquake Chronology for the last 4,000 Years Inferred from VarveBounded Debris-Flow Deposits beneath an Inlet near Victoria, British Columbia, Bull. Seismol. Soc. Amer., 101, 1-12, 2011.

Blott, S. J. and Pye, K.: Particle size distribution analysis of sandsized particles by laser diffraction: an experimental investigation of instrument sensitivity and the effects of particle shape, Sedimentology, 53, 1-33, 2006.

Bouma, A. H.: Sedimentology of some flysch deposits: a graphic approach to facies interpretation, Wiley, New York, 1962.

Bowman, D., Korjenkov, A., and Porat, N.: Late-Pleistocene seismites from Lake Issyk-Kul, the Tien Shan range, Kyrghyzstan, Sediment. Geol., 163, 211-228, 2004.

Briles, C. E., Whitlock, C., and Bartlein, P. J.: Postglacial vegetation, fire, and climate history of the Siskiyou Mountains, Oregon, USA, Quaternary Res., 64, 44-56, 2005.

Briles, C. E., Whitlock, C., Bartlein, P. J., and Higuera, P.: Regional and local controls on postglacial vegetation and fire in the Siskiyou Mountains, northern California, USA, Palaeogeogr. Palaeocl., 265, 159-169, 2008.

Brothers, D. S., Kent, G. M., Driscoll, N. W., Smith, S. B., Karlin, R., Dingler, J. A., Harding, A. J., Seitz, G. G., and Babcock, J. M.: New Constraints on Deformation, Slip Rate, and Timing of the Most Recent Earthquake on the West Tahoe-Dollar Point Fault, Lake Tahoe Basin, California, B. Seismol. Soc. Am., 99, 499-519, 2009.

Brown, S. L., Bierman, P. R., Lini, A., and Southon, J.: 10000 yr record of extreme hydrologic events, Geology, 28, 335-338, 2000.

Carrillo, E., Beck, B., Audemard, F. A., Moreno, E., and O1larves, R.: Disentangling Late Quaternary climatic and seismotectonic controls on Lake Mucubaji sedimentation (Merida Andes, Venezuela), Palaeogeogr. Palaeocl., 259, 284-300, 2008.

Chapron, E., Beck, C., Pourchet, M., and Deconinck, J.-F.: 1822 earthquake-triggered homogenite in Lake Le Bourget (NW Alps), Terra Nova, 11, 86-92, 1999.

Charlet, F., De Batist, M., Chapron, E., Bertrand, S., Pino, M., and Urrutia, R.: Seismic stratigraphy of Lago Puyehue (Chilean Lake 
District): new views on its deglacial and Holocene evolution, J. Paleolimnol., 39, 163-177, 2008.

Cita, M. B. and Aloisi, G.: Deep-sea tsunami deposits triggered by the explosion of Santorini (3500 y BP), eastern Mediterranean, Sediment. Geol., 135, 181-203, 2000.

Colombaroli, D. and Gavin, D. G.: Highly episodic fire and erosion regime over the past 2,000 y in the Siskiyou Mountains, Oregon, P. Natl. Acad. Sci. USA, 107, 18909-18914, 2010.

Dallimore, A., Enkin, R. J., and Southon, J. R.: Post-glacial and paleo-environmental history of the west coast of Vancouver Island, AGU (American Geophysical Union) Annual General Meeting, San Francisco, December, 2005.

Dallimore, A., Enkin, R. J., Baker, J., and Peinitz, R.: Stratigraphy and late Pleistocene-Holocene history of Effingham Inlet, B.C. Results from MONA Core MD02-2494 and GSC freeze cores, Geological Survey of Canada, Open-File Report 5930, 16 pp., 2009.

Dearing, J. A. and Jones, R. T.: Coupling temporal and spatial dimensions of global sediment flux through lake and marine sediment records, Global Planet. Change, 39, 147-168, 2003.

Doig, R.: A method for determining the frequency of largemagnitude earthquakes using lake sediments, Can. J. Earth Sci., 23, 930-937, 1986.

Doig, R.: 2300 yr history of seismicity from silting events in Lake Tadousac, Charlevois, Québec, Geology, 18, 820-823, 1990.

Doig, R.: Effects of strong seismic shaking in lake sediments, and earthquake recurrence interval, Temiscaming, Québec, Can. J. Earth Sci., 28, 1349-1352, 1991.

Doughty, M., Eyles, N., and Daurio, L.: Earthquake-triggered slumps (1935 Timiskaming M6.2) in Lake Kipawa, Western Québec Seismic Zone, Canada, Sediment. Geol., 228, 113-118, 2010.

Duffin, K. I., Gillson, L., and Willis, K. J.: Testing the sensitivity of charcoal as an indicator of fire events in savanna environments: Quantitative predictions of fire proximity, area and intensity, The Holocene, 18, 279-291, 2008.

Duncan, J. R.: Late Pleistocene and postglacial sedimentation and stratigraphy of deep-sea environments off Oregon [PhD thesis], unpublished $\mathrm{PhD}$ thesis, Corvallis, OR, Oregon State University, 243 pp., 1968.

Dziak R. P., Fox C. G., Bobbitt A. M., and Goldfinger C.: Bathymetric map of the Gorda plate: structural and geomorphological processes inferred from multibeam surveys, Mar. Geophys. Res., 22, 235-250, 2001.

Gedye, S. J., Jones, R. T., Tinner, W., Ammann, B., and Oldfield, F.: The use of mineral magnetism in the reconstruction of fire history: a case study from Lago di Origlio, Swiss Alps, Palaeogeogr. Palaeoclim., 164, 101-110, 2000.

Gilli, A., Anselmetti, F. S., Glur, L., and Wirth, S. B.: Lake Sediments as Archives of Recurrence Rates and Intensities of Past Flood Events, in: Dating Torrential Processes on Fans and Cones, edited by: Schneuwly-Bollschweiler, Stoffel, M. AND Rudolf-Miklau, F. Adv. Glob. Change Res., 47, 225-242, doi:10.1007/978-94-007-4336-6 15, 2013.

Goldfinger, C., Nelson, C. H., and Johnson, J. E.: Deep-Water Turbidites as Holocene Earthquake Proxies: The Cascadia Subduction Zone and Northern San Andreas Fault Systems, Annali Geofisica, 46, 1169-1194, 2003a.
Goldfinger, C., Nelson, C. H., and Johnson, J. E.: Holocene Earthquake Records From the Cascadia Subduction Zone and Northern San Andreas Fault Based on Precise Dating of Offshore Turbidites, Annu. Rev. Earth Pl. Sc., 31, 555-577, 2003 b.

Goldfinger, C., Morey, A. E., Nelson, C. H., Gutierrez-Pastor, J., Johnson, J. E., Karabanov, E., Chaytor, J., and Ericsson, A.: Rupture Lengths and Temporal History of Significant Earthquakes on the Offshore and North Coast Segments of the Northern San Andreas Fault Based on Turbidite Stratigraphy, Earth Planet. Sc. Lett., 254, 9-27, 2007.

Goldfinger, C., Grijalva, K., Burgmann, R., Morey, A. E., Johnson, J. E., Nelson, C. H., Gutierrez-Pastor, J., Karabanov, E., Chaytor, J. D., Patton, J., and Gracia, E.: Late Holocene Rupture of the Northern San Andreas Fault and Possible Stress Linkage to the Cascadia Subduction Zone, B. Seismol. Soc. Am., 98, 861-889, 2008.

Goldfinger, C., Patton, J., Morey, A. E., and Nelson, C. H.: Reply to "Comment on Late Holocene Rupture of the Northern San Andreas Fault and Possible Stress Linkage to the Cascadia Subduction Zone”, B. Seismol. Soc. Am., 99, 2599-2606, 2009.

Goldfinger, C., Ikeda, Y., Yeats, R. S., ANDRen, J.: Superquakes and Supercycles, Seismol. Res. Letters, 84, 1-9, 2013.

Goldfinger, C., Nelson, C. H., Morey, A., Johnson, J. E., GutierrezPastor, J., Eriksson, A. T., Karabanov, E., Patton, J., Gracia, E., Enkin, R., Dallimore, A., Dunhill, G., and Vallier, T.: Turbidite Event History: Methods and Implications for Holocene Paleoseismicity of the Cascadia Subduction Zone, Reston, VA, U.S. Geological Survey, USGS Professional Paper 1661-F, 362, 184 pp., 2012.

Gorsline, D. S., De Diego, T., and Nava-Sanchez, E. H.: Seismically triggered turbidites in small margin basins: Alfonso Basin, Western Gulf of California and Santa Monica Basin, California Borderland, Sediment. Geol., 135, 21-35, 2000.

Gràcia, E., Vizcaino, A., Escutia, C., Asioli, A., Rodés, Á., Pallàs, R., Garcia-Orellana, J., Lebreiro, S., and Goldfinger, C.: Holocene earthquake record offshore Portugal (SW Iberia): testing turbidite paleoseismology in a slow-convergence margin, Quaternary Sci. Rev., 29, 1156-1172, 2010.

Grantz, A., Phillips, R. L., Mullen, M. W., Starratt, S. W., Jones, G. A., Naidu, S. S., and Finney, B. P.: Character, paleoenvironment, rate of accumulation, and evidence for seismic triggering of Holocene turbidites, Canada abyssal plain, Arctic Ocean, Mar. Geol., 133, 51-73, 1996.

Griggs, G. B.: Cascadia Channel: The anatomy of a deep sea channel [Ph.D. thesis], unpublished PhD thesis, Corvallis, OR, Oregon State University, 225 pp., 1969.

Griggs, G. B., and Kulm, L. D.: Sedimentation in Cascadia DeepSea Channel, Geol. Soc. Am. Bulletin, 81, 1361-1384, 1970.

Gutiérrez-Pastor, J., Nelson, C. H., Goldfinger, C., and Escutia, C.: Sedimentology of seismo-turbidites off the Cascadia and northern California active tectonic continental margins, northwest $\mathrm{Pa}$ cific Ocean, Mar. Geol., 336, 99-119, 2013.

Guyard, H., St-Onge, G., Chapron, E., Anselmetti, F., and Francus, P.: The AD 1881 Earthquake-Triggered Slump And Late Holocene Flood-Induced Turbidites From Proglacial Lake Bramant, Western French Alps, Submarine Mass Movements and Their Consequences, 279-286, 2007.

Hagstrum, J. T., Atwater, B. F., and Sherrod, B. L.: Paleomagnetic correlation of late Holocene earthquakes among estuaries in 
Washington and Oregon, Geochem. Geophy. Geosy., 5, Q10001, doi:10.1029/2004GC000736, 2004.

Higuera, P. E., Peters, M. E., Brubaker, L. B., and Gavin, D. G.: Understanding the origin and analysis of sediment-charcoal records with a simulation model, Quaternary Sci. Rev., 26, 1790-1809, 2007.

Hodgson, E. A.: Preliminary report of the earthquake of November 1, 1935, Earthquake Notes 7, 1-4, 1936a.

Hodgson, E. A.: The Temiskaming earthquake of November 1, 1935: the location of epicentre and determination of focal depth, J. Roy. Astron. Soc. Can., 30, 113-123, 1936b.

Howarth, J. D., Fitzsimons, S. J., Norris, R. J., and Jacobsen, G. E.: Lake sediments record cycles of sediment flux driven by large earthquakes on the Alpine fault, New Zealand, Geology, 40, 1091-1094, 2012.

Inouchi, Y., Kinugasa, Y., Kumon, F., Nakano, S., Yasumatsu, S., and Shiki, T.: Turbidites as records of intense palaeoearthquakes in Lake Biwa, Japan, Sediment. Geol., 104, 117-125, 1996.

Iwaki, H., Hayashida, A., Kitada, N., Ito, H., Suwa, S., and Takemura, K.: Stratigraphic correlation of samples from the Osaka Bay off Kobe based on magnetic properties and its implication for tectonic activity of the Osaka-wan fault for the last 6300 years, EOS T. Am. Geophys. Un., 84, GP41C-0053 F554, 2004.

Karlin, R. and Abella, S. E.: A history of Pacific Northwest earthquakes recorded in Holocene sediments from Lake Washington, J. Geophys. Res., 101, 6137-6150, doi:10.1029/95JB01626, 1996.

Karlin, R. C. and Abella, S. E.: Paleoearthquakes in the Puget Sound region recorded in sediments from Lake Washington, U.S.A., Science, 258, 1617-1620, 1992.

Karlin, R. E., Holmes, M., Abella, S. E. B., and Sylwester, R.: Holocene landslides and a 3500-year record of Pacific Northwest earthquakes from sediments in Lake Washington, Geol. Soc. Am. Bull., 116, 94-108, 2004.

Kastens, K. A.: Earthquakes as a triggering mechanism for debris flows and turbidites on the Calabrian Ridge, Mar. Geol., 55, 1333, 1984.

Kelsey, H. M., Nelson, A. R., Hemphill-Haley, E., and Witter, R. C.: Tsunami history of an Oregon coastal lake reveals a 4600 $\mathrm{yr}$ record of great earthquakes on the Cascadia subduction zone, GSA Bulletin, 117, 1009-1032, 2005.

Kent, G. M., Babcock, J. M., Driscoll, N. W., Harding, A. J., Dingler, J. A., Seitz, G. G., Gardner, J. V., Mayer, L. A., Goldman, C. R., Heyvaert, A. C., Richards, R. C., Karlin, R., Morgan, C. W., Gayes, P. T., and Owen, L. A.: 60 k.y. record of extension across the western boundary of the Basin and Range province: Estimate of slip rates from offset shoreline terraces and a catastrophic slide beneath Lake Tahoe, Geology, 33, 365-368, 2005.

Kneller, B. C. and McCaffrey, W. D.: The interpretation of vertical sequences in turbidite beds: the influence of longitudinal flow structure, J. Sediment. Res., 73, 706-713, 2003.

Kulbe, T., Anselmetti, F., Cantonati, M., and Strum, M.: Environmental history of Lago di Tovel, Trento, Italy revealed by sediment cores and $3.5 \mathrm{kHz}$ seismic mapping, J. Paleolimnol., 34, 325-337, 2005.

Kulm, L. D., Roush, R. C., Harlett, J. C., Neudeck, R. H., Chambers, D. M., and Runge, E. J.: Oregon continental shelf sedimentation: Interrelationships of facies distribution and sedimentary processes, J. Geol., 83, 145-175, 1975.
Lauterbach, S., Chapron, E., Brauer, A., Hüls, M., Gilli, A., Arnaud, F., Piccin, A., Nomade, J., Desmet, M., and von Grafenstein, U.: A sedimentary record of Holocene surface runoff events and earthquake activity from Lake Iseo (Southern Alps, Italy), Holocene, 22, 749-760, 2012.

Lee, S.-J., Huang, B.-S., Ando, M., Chin, H.-C., and Wang, J.H.: Evidence of large scale repeating slip during the 2011 Tohoku-Oki earthquake, Geophys. Res. Lett., 38, L19306, doi:10.1029/2011GL049580, 2011.

Lees, J. A., Flower, R. J., Ryves, D., Vologina, E., and Sturm, M.: Identifying sedimentation patterns in Lake Baikal using whole core and surface scanning magnetic susceptility, J. Paleolimnol., 20, 187-202, 1998.

Long, C. J. and Whitlock, C.: Fire and Vegetation History from the Coastal Rain Forest of the Western Oregon Coast Range, Quaternary Res., 58, 215-225, 2002.

Long, C. J., Whitlock, C., Bartlein, P. J., and Millspaugh, S. H.: A 9000-year fire history from the Oregon Coast Range, based on a high-resolution charcoal study, Can. J. Forest Res., 28, 774-787, 1998.

Long, C. J., Whitlock, C., and Bartlein, P. J.: Holocene vegetation and fire history of the Coast Range, western Oregon, USA, Holocene, 17, 917-926, doi:10.1177/0959683607082408, 2007.

Marco, S., Stein, M., Agnon, A., and Ron, H.: Long-term earthquake clustering: A 50,000-year paleoseismic record in the Dead Sea Graben, J. Geophys. Res., 101, 6179-6191, 1996.

McHugh, C. M., Seeber, L., Braudy, N., Cormier, M.-H., Davis, M. B., Diebold, J. B., Dieudonne, N., Douilly, R., Gulick, S. P. S., Hornbach, M. J., Johnson III, H. E., Mishkin, K. R., Sorlien, C. C., Steckler, M. S., Symithe, S. J., and Templeton, J.: Offshore sedimentary effects of the 12 January 2010 Haiti earthquake, Geology, 39, 723-726, 2011.

Migowski, C., Agnon, A., Bookman, R., Negendank, J. F. W., and Stein, M.: Recurrence pattern of Holocene earthquakes along the Dead Sea transform revealed by varve-counting and radiocarbon dating of lacustrine sediments, Earth Planet. Sc. Lett., 222, 301$314,2004$.

Millspaugh, S. H. and Whitlock, C.: A 750-year fire history based on lake sediment records in central Yellowstone National Park, Holocene, 5, 283-292, 1995.

Millspaugh, S. H., Whitlock, C., and Bartlein, P. J.: Variations in fire frequency and climate over the last 17,000 years in central Yellowstone National Park, Geology, 28, 211-214, 2000.

Moernaut, J.: Giant earthquakes in south-central Chile revealed by Holocene mass-wasting events in Lake Puyehue, Sediment Geol., 195, 239-256, doi:10.1016/j.sedgeo.2006.08.005, 2007.

Mulder, T., Migeon, S., Savoye, B., and Faugères, J.-C.: Inversely graded turbidite sequences in the deep Mediterranean: a record of deposits from flood-generated turbidity currents?, Geo-Mar. Lett., 21, 86-93, 2001.

Mulder, T., Syvitski, J. P. M., Migeon, S., Faugeres, J. C., and Savoye, B.: Marine hyperpycnal flows; initiation, behavior and related deposits; a review: Turbidites; models and problems, Mar. Petrol. Geol., 20, 861-882, 2003.

Nakajima, T.: Initiation processes of turbidity currents; implications for assessments of recurrence intervals of offshore earthquakes using turbidites, Bulletin of the Geological Survey of Japan, 51, 79-87, 2000 
Nakajima, T. and Kanai, Y.: Sedimentary features of seismoturbidites triggered by the 1983 and older historical earthquakes in the eastern margin of the Japan Sea, Sediment. Geol., 135, 1-19, 2000.

Nelson, C. H.: Late Pleistocene and Holocene depositional trends, processes, and history of Astoria Deep-Sea Fan, northeast Pacific, Mar. Geol., 20, 129-173, 1976.

Nelson, C. H., Karabanov, E. B., and Colman, S. M.: Late Quaternary Lake Baikal turbidite systems, Russia: in: An Atlas of Deep-Water Environments, edited by: Pickering, K. T., Lucchi, F. R., Smith, R., Hiscott, R. N., and Kenyon, N., Chapman and Hall, London, 29-33, 1995.

Niemi, T. M. and Ben-Avraham, Z.: Evidence for Jericho earthquakes from slumped sediments of the Jordan River delta in the Dead Sea, Geology, 22, 395-398, 1994.

Noda, A.: Turbidites along Kushiro Canyon, in: Workshop on Turbidites as Earthquake Recorders: Tsukuba, Japan, AIST, edited by: Satake, K. and Goldfinger, C., Geological Survey of Japan, 2004.

Noren, A. J., Bierman, P. R., Steig, E. J., Lini, A., and Southon, J.: Millennial-scale storminess variability in the northeastern United States during the Holocene epoch, Nature, 419, 821-824, 2002.

Obermeier, S. F.: Using Liquefaction-Induced and Other SoftSediment Features for Paleoseismic Analysis, International Geophysics, 95, 497-564, 2009.

Orpin, A. R., Carter, L., Rogers, K. M., Page, M. J., Cochran, U. A., Trustrum, N. A., Gomez, B., Palmer, A. S., Mildenhall, D. C., Rogers, K. M., Brackley, H. L., and Northcote, L.: Holocene sedimentary record from Lake Tutira: A template for upland watershed erosion proximal to the Waipaoa Sedimentary System, northeastern New Zealand, Mar. Geol., 270, 11-29, 2010.

Ouellet, M.: Lake sediments and Holocene seismic hazard assessment within the St. Lawrence Valley, Québec, Geol. Soc. Am. Bull., 109(6), 631-642, 1997.

Pareschi, M. T., Boschi, E., and Favalli, M.: Lost tsunami, Geophys. Res. Lett., 33, L22608, doi:10.1029/2006GL027790, 2006.

Parris, A. S., Bierman, P. R., Noren, A. J., Prins, M. A., and Lini, A.: Holocene paleostorms identified by grain-size signatures in lake sediments from the northeastern United States, J. Paleolimnol., 43, 29-49, 2010

Patton, J. R., Goldfinger, C., Morey, A., Erhardt, M., Black, B., Garrett, A. M., Djadjadihardja, Y. S., and Hanifa, U.: Temporal Clustering and Recurrence of Holocene Paleoearthquakes in the Region of the 2004 Sumatra-Andaman Earthquake, Seismological Society of America Annual Meeting, Portland, OR, 41, p. 408, 2010.

Patton, J. R., Goldfinger, C., Morey, A. E., Romsos, C., Black, B., Djadjadihardja, Y., and Udrekh: Seismoturbidite record as preserved at core sites at the Cascadia and Sumatra-Andaman subduction zones, Nat. Hazards Earth Syst. Sci., 13, 833-867, doi:10.5194/nhess-13-833-2013, 2013.

Pilkey, O. H.: Basin plains; Giant sedimentation events, Geol. S. Am. S., 229, 93-99, 1988.

Pouderoux, H., Proust, J.-N., Lamarche, G., Orpin, A., and Neil, H.: Postglacial (after $18 \mathrm{ka}$ ) deep-sea sedimentation along the Hikurangi subduction margin (New Zealand): Characterisation, timing and origin of turbidites, Mar. Geol., 295-298, 51-76, 2012.

Prichard, S. J., Gedalof, Z., Oswald, W. W., and Peterson, D. L.: Holocene fire and vegetation dynamics in a montane forest,
North Cascade Range, Washington, USA, Quaternary Res., 72, 57-67, 2009.

Raymond, R. B.: The paleolimnology of Bull Run Lake: disruption and stability in a natural system, Portland State University, unpublished $\mathrm{Ph} . \mathrm{D}$. thesis, available at: http://dr.archives.pdx.edu/ xmlui/handle/psu/4382 (last access: 23 September 2013), 1983.

Reimer, P. J. and Reimer, R. W.: A marine reservoir correction database and on-line interface, Radiocarbon, 43, 461-463, 2001 (supplemental material available at: http://www.calib.org).

Schnellmann, M., Anselmetti, F. S., Giardini, D., McKenzie, J. A., and Ward, S. N.: Prehistoric earthquake history revealed by lacustrine slump deposits, Geology, 30, 1131-1134, 2002.

Schnellmann, M., Anselmetti, F. S., Giardini, D., and McKenzie, J. A.: 15,000 Years of mass-movement history in Lake Lucerne: Implications for seismic and tsunami hazards, Eclogae Geol. Helv., 99, 409-428, 2006.

Seitz, G. G. and Kent, G. M.: Closing the Gap between On and Offshore Paleoseismic Records in the Lake Tahoe Basin, US Geological Survey, NEHRP Annual Report, 34, 14 pp., 2005.

Shiki, T.: Reading of trigger records of sedimentary events-a problem for future studies, Sediment Geol., 104, 244-255, 1996.

Shiki, T., Cita, M. B., and Gorsline, D. S.: Sedimentary features of seismites, seismo-turbidites and tsunamiites an introduction, Sediment. Geol., 135, 7-9, 2000a.

Shiki, T., Kumon, F., Inouchi, Y., Kontani, Y., Sakamoto, T., Tateishi, M., Matsubara, H., and Fukuyama, K.: Sedimentary features of the seismo-turbidites, Lake Biwa, Japan, Sediment. Geol., 135, 37-50, 2000b.

Simonneau, A., Chapron, E., Vannière, B., Wirth, S. B., Gilli, A., Di Giovanni, C., Anselmetti, F. S., Desmet, M., and Magny, M.: Mass-movement and flood-induced deposits in Lake Ledro, southern Alps, Italy: implications for Holocene palaeohydrology and natural hazards, Clim. Past, 9, 825-840, doi:10.5194/cp-9825-2013, 2013.

Smoot, J. P., Litwin, R. J., Bischoff, J. L., and Lund, S. P.: Sedimentary record of the 1872 earthquake and "Tsunami" at Owens Lake, southeast California, Sediment. Geol., 135, 241254, 2000.

St-Onge, G. and Lajeunesse, P.: Flood-Induced Turbidites From Northern Hudson Bay And Western Hudson Strait: A Two-Pulse Record Of Lake Agassiz Final Outburst Flood?, Submarine Mass Movements and Their Consequences, 129-137, 2007.

St-Onge, G., Chapron, E., Mulsow, S., Salas, M., Viel, M., Debret, M., Foucher, A., Mulder, T., Winiarski, T., Desmet, M., Costa, P. J. M., Ghaleb, B., Jaouen, A., and Locat, J.: Comparison of earthquake-triggered turbidites from the Saguenay (Eastern Canada) and Reloncavi (Chilean margin) Fjords: Implications for paleoseismicity and sedimentology, Sed. Geol., 43-244, 89-107, 2012.

St-Onge, G., Stoner, J. S., and Hillaire-Marcel, C.: Holocene paleomagnetic records from the St. Lawrence Estuary, eastern Canada: centennial- to millennial-scale geomagnetic modulation of cosmogenic isotopes, Earth Planet. Sc. Lett., 209, 113-130, 2003.

St-Onge, G., Mulder, T., Piper, D. J. W., Hillaire-Marcel, C., and Stoner, J. S.: Earthquake and flood-induced turbidites in the Saguenay Fjord (Québec): a Holocene paleoseismicity record, Quaternary Sci. Rev., 23, 283-294, 2004

Strasser, M., Anselmetti, F. S., Fäh, D., Giardini, D., and Schnellmann, M.: Magnitudes and source areas of large prehistoric 
northern Alpine earthquakes revealed by slope failures in lakes, Geology, 34, 1005-1008, 2006.

Strasser, M., Stegmann, S., Bussmann, F., Anselmetti, F. S., Rick, B., and Kopf, A.: Quantifying subaqueous slope stability during seismic shaking: Lake Lucerne as model for ocean margins, Mar. Geol., 240, 77-97, 2007.

Strasser, M., Hilbe, M., and Anselmetti, F. S.: Mapping basin-wide subaquatic slope failure susceptibility as a tool to assess regional seismic and tsunami hazards, Mar. Geophys. Res., 32, 331-347, 2011.

Sturm, M., Siegenthaler, C., and Pickrill, R. A.: Turbidites and "homogenites" - a conceptual model of flood and slide deposits, Publication of IAS-16th regional meeting sedimentology, Paris, 22, p. $140,1995$.

Sumner, E. J., Amy, L. A., and Talling, P. J.: Deposit structure and processes of sand deposition from decelerating sediment suspensions, 78, 529-547, 2008.

Thompson, R. and Oldfield, F.: Environmental magnetism, Allen \& Unwin, London, 1986.

Tripsanas, E. K., Piper, D. J. W., Jenner, K. A., and Bryant, W. R.: Submarine mass-transport facies: New perspectives on flow processes from cores on the eastern North American margin, Sedimentology, 55, 97-136, 2008.

Twitchell, D. C., Cross, V. A., Hanson, A. D., Buck, B. J., Zybala, J. G., and Rudin, M. J.: Seismic architecture and lithofacies of turbidites in Lake Mead (Arizona and Nevada, U.S.A.), an analogue for topographically complex basins, J. Sediment. Res., 75, 134-148, 2005.

Waldmann, N., Ariztegui, D., Anselmetti, F. S., Austin, J. A., Dunbar, R., Moy, C. M., and Recasens, C.: Seismic stratigraphy of Lago Fagnano sediments (Tierra del Fuego, Argentina); a potential archive of paleoclimatic change and tectonic activity since the Late Glacial, Geol. Acta, 6, 101-110, 2008.
Walsh, M. K., Pearl, C. A., Whitlock, C., Bartlein, P. J., and Worona, M. A.: An 11,000-year-long record of fire and vegetation history at Beaver Lake, Oregon, central Willamette Valley, Quaternary Sci. Rev., 29, 1093-1106, 2010.

Westerling, A. L., Hidalgo, H. G., Cayan, D. R., Swetnam, T. W.: Warming and earlier spring increase western U.S. forest wildfire activity, Science, 313, 940-943, 2006.

Whitlock, C. and Larsen, C. P. S.: Charcoal as a Fire Proxy. Tracking Environmental Change Using Lake Sediments, Kluwer, Dordrecht, the Netherlands, 3, 75-97, 2001.

Whitlock, C., Shafer, S. L., and Marlon, J.: The role of climate and vegetation change in shaping past and future fire regimes in the northwestern US and the implications for ecosystem management, Forest Ecol. Manag., 178, 5-21, 2003.

Whitlock, C., Marlon, J., Briles, C. E., Brunelle, A., Long, C., and Bartlein, P.: Long-Term Relations Among Fire, Fuel, And Climate In The North-Western US Based On Lake-Sediment Studies, Int. J. Wildland Fire, 17, 72-83, 2008.

Wirth, S. B., Girardclos, S., Rellstab, C., and Anselmetti, F. S.: The sedimentary response to a pioneer geo-engineering project: Tracking the Kander River deviation in the sediments of Lake Thun (Switzerland), Sedimentology, 58, 1737-1761, 2011.

Wynn, R. B., Weaver, P. P. E., Masson, D. G., and Stow, D. A. V.: Turbidite depositional architecture across three interconnected deep-water basins on Northwest African margin, Sedimentology, 49, 661-695, 2002.

Zdanowicz, C. M., Zielinski, G. A., and Germani, M. S.: Mount Mazama eruption: Calendrical age verified and atmospheric impact assessed, Geology, 27, 621-624, 1999. 